\title{
Development of an Efficient Protein Extraction Method Compatible with LC-MS/MS for Proteome Mapping in Two Australian Seagrasses Zostera muelleri and Posidonia australis
}

\section{OPEN ACCESS}

Edited by:

Karl-Josef Dietz,

Bielefeld University, Germany

Reviewed by:

Sudisha Jogaiah,

Karnatak University, India

Silvia Mazzuca

University of Calabria, Italy

*Correspondence:

Manoj Kumar

manoj.kumar@uts.edu.au

${ }^{\dagger}$ These authors have contributed equally to this work.

Specialty section:

This article was submitted to

Plant Abiotic Stress,

a section of the journal

Frontiers in Plant Science

Received: 12 April 2017

Accepted: 31 July 2017

Published: 15 August 2017

Citation:

Jiang Z, Kumar M, Padula MP

Pernice M, Kahlke T, Kim M and Ralph PJ (2017) Development of an Efficient Protein Extraction Method Compatible with LC-MS/MS for Proteome Mapping in Two Australian Seagrasses Zostera muelleri and Posidonia australis.

Front. Plant Sci. 8:1416. doi: 10.3389/fp/s.2017.01416

\author{
Zhijian Jiang ${ }^{1,2 \dagger}$, Manoj Kumar ${ }^{2 \star}$, Matthew P. Padula ${ }^{3}$, Mathieu Pernice $^{2}$, Tim Kahlke ${ }^{2}$, \\ Mikael Kim ${ }^{2}$ and Peter J. Ralph ${ }^{2}$
}

${ }^{1}$ Key Laboratory of Tropical Marine Bio-resources and Ecology, South China Sea Institute of Oceanology, Chinese Academy of Sciences, Guangzhou, China, ${ }^{2}$ Climate Change Cluster (C3), Faculty of Science, University of Technology Sydney (UTS), Sydney, NSW, Australia, ${ }^{3}$ Proteomics Core Facility, University of Technology Sydney (UTS), Sydney, NSW, Australia

The availability of the first complete genome sequence of the marine flowering plant Zostera marina (commonly known as seagrass) in early 2016, is expected to significantly raise the impact of seagrass proteomics. Seagrasses are marine ecosystem engineers that are currently declining worldwide at an alarming rate due to both natural and anthropogenic disturbances. Seagrasses (especially species of the genus Zostera) are compromised for proteomic studies primarily due to the lack of efficient protein extraction methods because of their recalcitrant cell wall which is rich in complex polysaccharides and a high abundance of secondary metabolites in their cells. In the present study, three protein extraction methods that are commonly used in plant proteomics i.e., phenol (P); trichloroacetic acid/acetone/SDS/phenol (TASP); and borax/polyvinyl-polypyrrolidone/phenol (BPP) extraction, were evaluated quantitatively and qualitatively based on two dimensional isoelectric focusing (2D-IEF) maps and LCMS/MS analysis using the two most abundant Australian seagrass species, namely Zostera muelleri and Posidonia australis. All three tested methods produced high quality protein extracts with excellent 2D-IEF maps in P. australis. However, the BPP method produces better results in $Z$. muelleri compared to TASP and P. Therefore, we further modified the BPP method (M-BPP) by homogenizing the tissue in a modified protein extraction buffer containing both ionic and non-ionic detergents (0.5\% SDS; $1.5 \%$ Triton X-100), 2\% PVPP and protease inhibitors. Further, the extracted proteins were solubilized in $0.5 \%$ of zwitterionic detergent (C7BzO) instead of $4 \% \mathrm{CHAPS}$. This slight modification to the BPP method resulted in a higher protein yield, and good quality 2-DE maps with a higher number of protein spots in both the tested seagrasses. Further, the MBPP method was successfully utilized in western-blot analysis of phosphoenolpyruvate carboxylase (PEPC - a key enzyme for carbon metabolism). This optimized protein extraction method will be a significant stride toward seagrass proteome mining and identifying the protein biomarkers to stress response of seagrasses under the scenario of global climate change and anthropogenic perturbations.

Keywords: seagrass, proteomics, 2D-IEF, Zostera muelleri, Posidonia australis, LC-MS/MS 


\section{INTRODUCTION}

Seagrasses (marine flowering plants), are marine ecological engineers delivering a range of ecologically and economically valuable biological services to marine aquatic ecosystems (Larkum et al., 2006). They are rated the third most valuable ecosystem globally with the average global value for their ecological services estimated at US $\$ 28,916 \mathrm{ha}^{-1} \mathrm{yr}^{-1}$ (Costanza et al., 2014). However, seagrasses are currently facing a global crisis and are declining at an alarming rate (by $>7 \% \mathrm{yr}^{-1}$ ) due to both natural and anthropogenic disturbances (Waycott et al., 2009).

Understanding of acclimation and/or tolerance mechanism of seagrasses to external perturbations is highly critical for developing strategies to prevent the loss of seagrass meadow (Davey et al., 2016; Kumar et al., 2016). Toward this, identification of biomarkers such as protein markers has been suggested as a possible solution that can provide early warning signals to prevent the seagrass meadow's demise before they pass the point of no return (Macreadie et al., 2014). Since, proteins respond dynamically to environmental fluctuations, the proteomics can provide novel insights into cellular pathways and biochemistry. To understand the change in state of the proteins, it is now common to perform a differential display of the proteome under contrasting conditions. Proteomics using advanced mass-spectrometry based approaches have had an increasing impact on the study of terrestrial plant responses to (a) biotic stresses (see references in Kumar et al., 2017). However, proteomics in seagrasses is still in its incipient stage for two primary reasons-(1) the lack of efficient protein extraction methods, and (2) limited availability of genomic sequence information. However, the recently published genome sequence of Zostera marina (Olsen et al., 2016) enables seagrass researchers to integrate additional-omics data types such as genomics and transcriptomics into their analysis of the physiological and molecular responses to environmental stress. Therefore, investigations into the seagrass proteome are important since proteins, unlike mRNA, are the direct effectors of the plant stress response.

Two-dimensional polyacrylamide gel electrophoresis (2-DE), established by O'Farrell, coupled with mass spectrometry (MS), is a cost effective and widely used proteomic technique. However, relatively expensive, alternative gel-free proteomic approaches such as isotopic labeling (iTRAQ and TMT) and Data Independent Acquisition (DIA/SWATH) are rapidly emerging (Hu et al., 2015). Irrespective of the technique used for proteomic studies, effective protein extraction and solubilization are unquestionably the critical factors in obtaining comprehensive proteome analysis. The comprehensive, unbiased extraction of protein from marine plants is particularly challenging due to their recalcitrant cell wall and low protein content. Moreover, their cell wall and vacuoles that make majority of the cell mass are associated with several secondary metabolites that strongly interfere with 2-DE, resulting in horizontal and vertical streaking, smearing, and reduced numbers of distinctly resolved protein spots (Wu et al., 2014a). The most common interfering substances in seagrasses are phenolic compounds, proteolytic and oxidative enzymes, terpenes, pigments, organic acids, and complex cell wall polysaccharides such as lignin (Papenbrock, 2012).

For recalcitrant plant tissues, protein extraction methods are typically based on trichloroacetic acid (TCA)/acetone washing or precipitation steps followed by phenol extraction. Recently, $\mathrm{Wu}$ et al. (2014b) formulated a "universal protein extraction protocol" for plant tissue by integrating TCA/acetone and phenol based methods with SDS extraction buffer to provide an improved 2-DE based proteomic analysis for most of the terrestrial plant tissues. However, TCA/acetone- and phenolbased methods are lengthy and involve multiple washing steps, resulting in unavoidable loss of protein. A protein extraction protocol designed for halophytes includes chemicals such as borax, polyvinyl-polypyrrolidone, phenol (BPP) and triton X100 in the extraction buffer, has been shown to be effective in removing interfering compounds and salts in a relatively shorter time without protein loss since it does not involve multiple washing steps (Wang et al., 2007). To date, no common and simple protocol exists for protein extraction that can be used on a large scale for marine plant proteomics, however few attempts have been undertaken previously to obtain well-resolved 1-DE and 2-DE images in seagrasses (Spadafora et al., 2008; Serra and Mazzuca, 2011 and references therein). There is a critical need for such a rapid and efficient protocol, especially for projects wherein comparative proteomic analysis is required for seagrass samples exposed naturally or in laboratory conditions to diverse a(biotic) stresses. Such protocols should also be effective for protein extraction for a range of marine plant species and also for different tissues.

In view of this and considering the fact that there are no reports on optimized protein extraction protocols for species of the genus Zostera, we compare three commonly used plant protein extraction methods (P, TASP, and BPP) for 2-DE separation. For this, the whole leaf tissue of two dominant seagrasses of Australia named Zostera muelleri and Posidonia australis were used as an experimental model.

\section{MATERIALS AND METHODS}

\section{Plant Material}

Samples of $Z$. muelleri were harvested from Narrabeen Lagoon (New South Wales, Australia) while samples of P. australis were collected from Ports Stephens (New South Wales, Australia). Turfs of seagrass with $10-15 \mathrm{~cm}$ of intact sediment were carefully removed from the meadow using a hand spade and placed in plastic tubs. Wet paper towels were placed over the plants to prevent desiccation during transport. Plants were transported back to the laboratory where they were cleaned of epiphytes and grazers. Additionally, any intact sediment was washed from roots and rhizome using natural filtered seawater of salinity $27 \mathrm{psu}$. The whole plant leaves were then separated at the horizontal creeping rhizome, and freezed at $-80^{\circ} \mathrm{C}$ for later use for total phenolics estimation and protein extraction. All the reagents used in this study (otherwise stated) were purchased from SigmaAldrich. 


\section{Total Phenolic Compound Estimation}

Total content of phenolic compounds was determined spectrophotometrically using Folin-Ciocalteu reagent following Kumar et al. (2011). In brief, methanolic extract $(0.4 \mathrm{~mL})$ obtained from $1 \mathrm{~g}$ fresh tissue was mixed with $0.15 \mathrm{~mL}$ of Folin-Ciocalteu's reagent. After $10 \mathrm{~min}$ incubation, $0.45 \mathrm{~mL}$ of $20 \%$ sodium carbonate solution was added, and the mixture was mixed thoroughly and allowed to stand at room temperature in the dark for $1 \mathrm{~h}$. Absorbance was measured at $725 \mathrm{~nm}$, and total content of phenolic compounds was calculated based on a standard curve of phloroglucinol.

\section{Protein Extraction}

Three commonly used protein extraction methods, phenol extraction, TCA/acetone/SDS-phenol extraction and borax/polyvinyl-polypyrrolidone/phenol extraction were evaluated using seagrass leaves (Figure 1). For each method, whole leaves of both $Z$. muelleri and $P$. australis ( $2 \mathrm{~g} \mathrm{FW})$ were pulverized using Retsch MM200 cryomill with a $1 \mathrm{~cm}$ stainless steel ball for $9 \mathrm{~min}$ in three cycles of $3 \mathrm{~min}$ each at a frequency of $30 / \mathrm{s}$. Later, the obtained fine talcum-like powder was used for protein extraction.

\section{Phenol (P) Method}

The powder was homogenized in $8 \mathrm{~mL}$ of buffer containing $50 \mathrm{mM}$ Tris- $\mathrm{HCl}$ (pH6.8), $5 \mathrm{mM}$ DTT, and $1 \mathrm{mM} \mathrm{PMSF}$, and vortexed for $5 \mathrm{~min}$. The homogenate was transferred into 2 $\mathrm{mL}$ eppendorf tubes and centrifuged at $15,000 \times \mathrm{g}$ and $4^{\circ} \mathrm{C}$ for 5 min. The supernatant (crude extract) was transferred to new tubes. Equal volumes of Tris-saturated phenol $(\mathrm{pH}$ 8.0) were added to the tubes and phenol extraction was performed using a methodology adapted from Wu et al. (2014a). The mixtures were thoroughly vortexed for $5 \mathrm{~min}$ and centrifuged as above for phase separation. The organic phase was transferred in new eppendorf tubes and precipitated using 5 volumes of $0.1 \mathrm{M}$ ammonium acetate in methanol at $-20^{\circ} \mathrm{C}$ overnight, and centrifuged as above. The precipitate was washed twice with $80 \%$ cold acetone. For each wash, $3 \mathrm{ml}$ of $80 \%$ cold acetone was added, and the precipitate was resuspended thoroughly by vortexing and centrifuged as above.

\section{Trichloroacetic Acid/Acetone/SDS/Phenol (TASP) Method}

This methodology was adapted from Wu et al. (2014b). The powder was resuspended in $8 \mathrm{~mL}$ of ice-cold 10\%TCA/acetone containing $10 \mathrm{mM}$ DTT and vortexed for $5 \mathrm{~min}$. The homogenate was then transferred to $2 \mathrm{~mL}$ Eppendorf tubes and centrifuged at $15,000 \times \mathrm{g}$ at $4^{\circ} \mathrm{C}$ for $5 \mathrm{~min}$. This step was repeated for four times, while re-suspending the pellet in cold TCA/acetone by pipetting and vortexing or drawing in and out of pellet with a $1.0 \mathrm{~mL}$ pipette. Finally, the precipitate was washed twice with cold acetone as described above in the phenol extraction. The pellet was collected and dried in fume hood to ensure that all of the acetone has evaporated. The dried pellet was resuspend in sodium dodecyl sulfate (SDS) extraction buffer [containing 1\% (w/v) SDS, 0.15 M Tris-HCl (pH 8.8), 0.1 M DTT, 1 mM EDTA, 2 $\mathrm{mM}$ PMSF and protease inhibitors cocktail (Roche, Germany)] and incubated at room temperature (RT) for $30 \mathrm{~min}$ followed by centrifugation at $15,000 \times \mathrm{g}$ at RT for $15 \mathrm{~min}$. The resultant supernatant was transferred into new $2 \mathrm{~mL}$ Eppendorf tubes and an equal volume of Tris-saturated phenol ( $\mathrm{pH} 7.8$ ) was added, vortexed well for $5 \mathrm{~min}$ and centrifuged at 15,000 $\times \mathrm{g}$ for $5 \mathrm{~min}$ at RT. The phenol phase (lower phase) containing the proteins was collected in new eppendorf tubes and mixed well after adding an equal volume of wash buffer [10 mM Tris- $\mathrm{HCl}(\mathrm{pH} 8.0), 1 \mathrm{mM}$ EDTA and $0.7 \mathrm{M}$ sucrose], followed by centrifugation as above. Later, the organic phase was collected in new $2 \mathrm{~mL}$ Eppendorf tubes and proteins were precipitated using 5 volumes of $0.1 \mathrm{M}$ ammonium acetate in methanol and washed as described above in "phenol extraction."

\section{Borax/Polyvinyl-Polypyrrolidone/Phenol (BPP) Method}

This methodology was adapted from Wang et al. (2007). The powder was resuspended in $8 \mathrm{~mL}$ ice-cold extraction buffer consisting of $100 \mathrm{mM}$ Tris ( $\mathrm{pH} 8.0$ ), $100 \mathrm{mM}$ EDTA, $50 \mathrm{mM}$ borax, $50 \mathrm{mM}$ ascorbic acid, 1\% PVPP w/v, 1\% Triton X-100 $\mathrm{v} / \mathrm{v}, 2 \% \beta$-mercaptoethanol $\mathrm{v} / \mathrm{v}$, and $30 \%$ sucrose w/v. After the sample was vortexed for $10 \mathrm{~min}$ at room temperature, two volumes of Tris-saturated Phenol ( $\mathrm{pH} \mathrm{8.0)}$ were added and the mixture further vortexed for $10 \mathrm{~min}$. After centrifugation at $15,000 \times \mathrm{g}$ for $15 \mathrm{~min}$ at $4^{\circ} \mathrm{C}$, the upper phase was transferred to a new centrifuge tube. An equal volume of extraction buffer was added into the new tube, the mixture was then vortexed for $10 \mathrm{~min}$, followed by centrifugation as above. The upper phase was then transferred to a new centrifuge tube and proteins were precipitated using 5 volumes of $0.1 \mathrm{M}$ ammonium acetate in methanol and washed as described above in "phenol extraction."

\section{Modified Borax/Polyvinyl-Polypyrrolidone/Phenol (M-BPP) Method}

This methodology was adapted from Wang et al. (2007). The powder (obtained by pulverizing the tissue in cryomill) was resuspended in $8 \mathrm{~mL}$ of ice-cold $\mathrm{BPP}$ extraction buffer as mentioned in the BPP method. However, the extraction buffer was slightly modified by additional incorporation of the ionic detergent-SDS $(0.5 \% \mathrm{w} / \mathrm{v})$ together with the non-ionic detergent $1.5 \%$ triton $X-100(v / v), 2 \%$ PVPP $(w / v)$, and protease inhibitor cocktail (Roche, Germany). The reagents SDS and PVPP were added in the extraction buffer from their stock solutions SDS $(20 \% \mathrm{w} / \mathrm{v})$ and PVPP $(10 \% \mathrm{w} / \mathrm{v})$ respectively. Protease inhibitor cocktail available commercially in the tablet form was dissolved in the extraction buffer (1 tablet/50 mL extraction buffer) using sonicator water bath. After the sample was vortexed for $10 \mathrm{~min}$ at room temperature, two volumes of Tris-saturated Phenol ( $\mathrm{pH} 8.0)$ were added and then the mixture was further vortexed for $10 \mathrm{~min}$. After centrifugation at $15,000 \times \mathrm{g}$ for 15 $\min$ at $4^{\circ} \mathrm{C}$, the upper phase was transferred to a new centrifuge tube. Equal volume of extraction buffer was added into the new tube, the mixture was then vortexed for $10 \mathrm{~min}$, followed by centrifugation as above. The upper phase was then transferred to a new centrifuge tube and proteins were precipitated using 5 volumes of $0.1 \mathrm{M}$ ammonium acetate in methanol and washed as described above in "phenol extraction." 


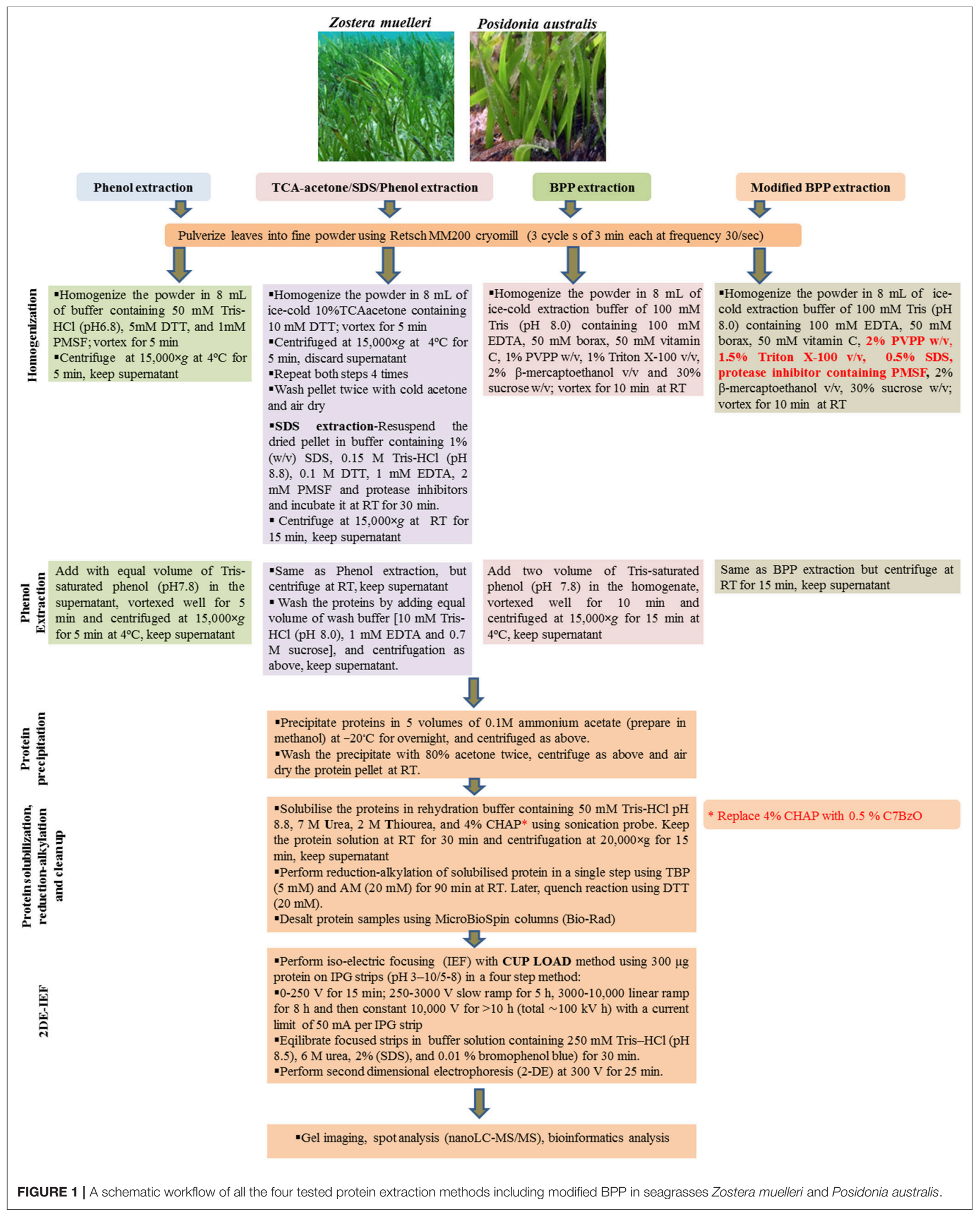




\section{Protein Solubilization, Alkylation-Reduction, and Quantification}

The precipitated proteins were solubilized in rehydration buffer containing $50 \mathrm{mM}$ Tris- $\mathrm{HCl} \mathrm{pH}$ 8.8, $7 \mathrm{M}$ Urea, $2 \mathrm{M}$ Thiourea and $4 \%$ CHAPS. However, for the M-BPP method we replaced CHAPS with $0.5 \% \mathrm{C7BzO}$ (UTC7). Solubilization was followed by the reduction and alkylation of disulfide bonds in a single step using tributylphosphine (reducing agent, $5 \mathrm{mM}$ ) and acrylamide monomers (alkylating agent, $20 \mathrm{mM}$ ) for $90 \mathrm{~min}$ at RT. The reaction was quenched using dithiothreitol (DTT, $20 \mathrm{mM}$ ). Protein samples were desalted using MicroBioSpin columns (Bio-Rad) equilibrated with UTC7 according to manufacturer's instructions, followed by centrifugation at $15,000 \times \mathrm{g}$ for $10 \mathrm{~min}$. The supernatant was collected for protein quantification and subsequent 2-DE analysis. Protein concentration was determined by SDS-PAGE and densitometry using bovine serum albumin as a standard.

\section{Two-Dimensional Electrophoresis (2-DE), Gel Scanning, and Image Analysis}

Protein $(300 \mu \mathrm{g})$ was separated by isoelectric focusing (IEF) using a cup-loading method according to Kumar et al. (2017). Immobilized $\mathrm{pH}$ gradient (IPG) strips (Bio-Rad, $\mathrm{pH} \mathrm{3-10} \mathrm{or} \mathrm{5-8,}$ $11 \mathrm{~cm}$ ) were passively rehydrated in UTC7 rehydration solution for a minimum of $6 \mathrm{~h}$ at room temperature. Isoelectric focusing was conducted in four steps as follows in a Protean IEF device (Bio-Rad): $250 \mathrm{~V}$ rapid ramp for $15 \mathrm{~min}, 4,000 \mathrm{~V}$ slow ramp for $8 \mathrm{~h}, 10,000 \mathrm{~V}$ linear ramp for $5 \mathrm{~h}$ and then constant $10,000 \mathrm{~V}$ for $>10 \mathrm{~h}$ (total $\sim 100 \mathrm{kV} \mathrm{h}$ ) with a current limit of $50 \mathrm{~mA}$ per IPG strip. The focused strips were then equilibrated in equilibration solution (containing $250 \mathrm{mM}$ Tris- $\mathrm{HCl}$ ( $\mathrm{pH} 8.5$ ), $6 \mathrm{M}$ urea, $2 \%$ (SDS), and $0.01 \%$ bromophenol blue) for $30 \mathrm{~min}$. Upon equilibration, the strips were directly applied onto a precast 4$20 \%$ polyacrylamide gel (Criterion ${ }^{\mathrm{TM}}$ IEF Precast Gels, Bio-Rad) for second dimension electrophoresis at constant voltage of 300 $\mathrm{V}$, for $25 \mathrm{~min}$. Gels were then fixed with $40 \%$ methanol, $10 \%$ acetic acid for $30 \mathrm{~min}$ before being stained with Coomassie Stain G250 and scanned at 600 dots per inch with fluorescence scanner (Typhoon FLA-3500), then analyzed using PDQuest 2-D analysis software, version 8.0 (Bio-Rad, USA). Molecular masses were estimated using a broad-range standard (Precision Plus, Bio-Rad) co-migrating in the SDS-PAGE.

\section{Protein Identification and Bioinformatics Analysis}

Randomly selected protein spots were excised from gels, trypsin digested, and analyzed by LC/MS/MS according to Kumar et al. (2017). Using an autosampler, connected to a nanoLC system (Tempo Eksigent, USA), $10 \mu \mathrm{L}$ of the sample was loaded at $20 \mu \mathrm{L} / \mathrm{min}$ with MS loading solvent (2\% Acetonitrile $+0.2 \%$ Trifluoroacetic Acid) onto a C8 trap column (CapTrap. Michrom Biosciences, USA). After washing the trap for $3 \mathrm{~min}$, the peptides were washed off the trap at $300 \mathrm{~nL} / \mathrm{min}$ onto a PicoFrit column $(75 \mu \mathrm{m} \times 100 \mathrm{~mm})$ packed with Magic C18AQ resin (Michrom Biosciences, USA). Peptides were eluted from the column and into the source of a QSTAR Elite hybrid Quadrupole-Time-ofFlight mass spectrometer (Applied Biosystems/MDS Sciex) using the following program: 5-50\% MS solvent B (98\% Acetonitrile $+0.2 \%$ Formic Acid) over $8 \mathrm{~min}, 50-80 \%$ MS buffer B over $5 \mathrm{~min}, 80 \%$ MS buffer $\mathrm{B}$ for $2 \mathrm{~min}, 80-5 \%$ for $3 \mathrm{~min}$. MS solvent A consisted of $2 \%$ Acetonitrile $+0.2 \%$ Formic Acid. The eluting peptides were ionized with a $75 \mu \mathrm{m}$ ID emitter tip that tapered to $15 \mu \mathrm{m}$ (New Objective) at 2,300 V. An Intelligent Data Acquisition (IDA) experiment was performed, with a mass range of 375-1,500 Da continuously scanned for peptides of charge state $2+$ to $5+$ with an intensity of more than 30 counts/s. Selected peptides were fragmented and the product ion fragment masses measured over a mass range of 100-1,500 Da. The mass of the precursor peptide was then excluded for $15 \mathrm{~s}$.

Peptides were identified and protein identity inferred using both Mascot (Daemon, v2.4) and PEAKS Studio software (Peaks Studio 8.1, Bioinformatics Solutions Inc., Waterloo, ON, Canada). The settings used were as follows-Fixed Modifications: none; Variable Modifications: deamidation, propionamide, oxidized methionine; Enzyme: semi-trypsin; Number of Allowed Missed Cleavages: 3; Peptide Mass Tolerance: 100 ppm; MS/MS Mass Tolerance: 0.2 Da; Charge State: $2+, 3+$, and 4+ (Kumar et al., 2017).

The results of the search were then filtered by including only protein hits with at least one unique peptide and excluding peptide hits with a $p>0.05$. Peptides were further validated by manual inspection of the MS/MS spectra for the peptide to ensure the $b$ - and $y$-ion series were sufficiently extensive for an accurate identification. For further protein identification, the Uniprot database of $Z$. marina and the customized database generated by converting ESTs of different seagrasses into protein sequences, were searched using PEAKS Studio v8.1 using the same parameters as Mascot. Later, the PEAKS studio search results were exported into a mzXML file and normalized and quantified using Scaffold Version 4.0 software. The threshold selection for the protein sequences was a PEAKS protein score $>20$ (the sum of the supporting peptide scores for each distinct sequence that are a representation of the $p$-value in PEAKS as a proxy of the LDF score, which measures the quality of the peptide-spectrum match; Kumar et al., 2017). Only proteins showing at least one peptide with an individual score confidence $>20$ in PEAKS, when the scaffold parameter was set at a protein threshold of $90 \%$ and peptide threshold of $95 \%$, were considered as valid candidates. For these proteins, MS/MS spectra were also manually validated by the presence of a series of at least four $y$-ions.

After PEAKS identification, protein sequences were analyzed using BLAST-P to determine similarity with known proteins in the NCBI database. The threshold was set to a minimal significance of $1 \mathrm{e}^{-3}$ and an identity percentage of $>25 \%$. The theoretical $\mathrm{p} I$ and molecular weight of the blast hit was calculated using the ExPASy tool (http://web.expasy.org/compute_pi/). The identified proteins were further annotated using InterproScan (Finn et al., 2017). The Gene Ontology terms were inferred using Interpro2GO (Gene Ontology Consortium, 2015). Subcellular localization of the proteins was assigned using Plant-mLoc (http://www.csbio.sjtu.edu.cn/bioinf/plant-multi/) and manually 
translated to Gene Ontology terms. GO terms were summarized using the GOSlimViewer tool included in AgBase based on the Plant GOSlim set (McCarthy et al., 2006).

\section{Western Blot Analysis}

About 2.5 to $25 \mu \mathrm{g}$ of the isolated proteins were separated via SDS-PAGE and then transferred onto a polyvinylidene difluoride (PVDF) membrane (GE Healthcare) for Western blotting analysis. Western blot analysis was carried out using a 1:500 polyclonal antibody raised against the evolutionarily conserved sequence of Arabidopsis thaliana PEPC purchased from Agrisera, Sweden (1:2,000 dilution) as primary antibody and a goat anti-rabbit IgG-labeled with horseradish peroxidase (HRP) as the secondary antibody. The detection of the immunocomplexes was performed by the Clarity ECL Substrate (Bio-Rad, Australia).

\section{Statistical Analysis}

The statistical results were presented as means $\pm S D$ (standard deviation) of three biological replicates. Statistical analysis, oneway ANOVA, tests was performed with 5\% level of significant using the SPSS software (version 12.0).

\section{RESULTS}

Among the four tested protein extraction methods (P, TASP, $\mathrm{BPP}$, and M-BPP), a modified BPP method (M-BPP) with the incorporation of $0.5 \%$ SDS, $1.5 \%$ Triton X-100, 2\% PVPP, and a protease inhibitor cocktail for protein extraction and $0.5 \%$ of the zwitterionic surfactant $\mathrm{C} 7 \mathrm{BzO}$ for protein solubilization, was found to produce most reproducible gels and highest protein yield $(0.79 \mathrm{mg} / \mathrm{g}$ fresh weight, FW) for Z. muelleri (Table 1). The protein extraction and 2D-IEF work flow for all the tested methods is outlined in Figure 1. M-BPP resulted in a dramatically higher number of protein spots (503, using $\mathrm{pH} 3$ 10 strip and 814 protein spots using $\mathrm{pH} 5-8$ strip), which was significantly higher when compared to other methods (Table 1). The protein yield and number of protein spots obtained in all the tested methods followed the order: $\mathrm{M}-\mathrm{BPP}>\mathrm{BPP}>\mathrm{TASP}>\mathrm{P}$ for $Z$. muelleri. In contrast, all the tested methods were equally good in obtaining a high protein yield with high protein spot numbers for $P$. australis. In general, M-BPP resulted in $40 \%$ and $15 \%$ higher protein spots in $Z$. muelleri and $P$. australis, respectively when compared to original BPP method.
Distinct qualitative and quantitative differences were noticed in the protein separation pattern between the methods examined in the present study. For example, in both $\mathrm{P}$ and TASP methods applied to $Z$. muelleri, the resolved proteins were restricted to a pI range between 5 and 7 and molecular weight of $10-60 \mathrm{KDa}$ with $183 \pm 22$ and $255 \pm 25$ protein spots, respectively (Table 1, Supplementary Figure 1). Interestingly, in the TASP method, Rubisco proteins (large subunit) were less abundant when compared to the $\mathrm{P}$ method (Supplementary Figures 1A,B) showing an inefficient extraction. Further, proteins within the molecular weight $(\mathrm{Mw})$ ranging from 12 to $20 \mathrm{kDa}$ and $\mathrm{pI} 4.0-5.25$ were more abundant in TASP and BPP extractions than in the $\mathrm{P}$ and M-BPP extractions (Supplementary Figure 1B, see the protein spots in red box). Protein identification of these protein spots selected from acidic region of the $2 \mathrm{D}$ gels of $Z$. muelleri is provided in Supplementary Table 1. In contrast, for P. australis proteins extracted by the P, TASP and BPP methods, most of the proteins were resolved within the $\mathrm{Mw} 10-100 \mathrm{KDa}$ and pI range 5-8 (Supplementary Figures $2 \mathrm{~A}-\mathrm{C}$ ). Interestingly, the M-BPP method extracted a range of proteins that are acidic in nature, pI range between 4 and 5 and $\mathrm{Mw} 10-80$ KDa (Supplementary Figure 2D, see the protein spots marked in red). Protein identification of these protein spots selected from acidic region of the $2 \mathrm{D}$ gels of $P$. australis is provided in Supplementary Table 1. Further, in the present study, the quantitative analysis of total polyphenolic compounds in leaf exhibited a significantly higher level $(>2$-fold) in $Z$. muelleri in contrast to $P$. australis (Figure 2).

Examination of the 2D-PAGE results for proteins extracted from whole leaves, the modified BPP protocol generated from several hundred (for $Z$. muelleri) to nearly thousand (for $P$. australis) protein spots with a broad distribution in both the horizontal and vertical separation dimensions, within the $\mathrm{pI}$ range between 3 and 10 (Supplementary Figures 1, 2), and pI 5-8 (Figures 3B, 4B) and the molecular weight range from 10 to $>100 \mathrm{KDa}$. The spots showed superior resolution with clear background and minimal streaking while the spot shape appeared round or elliptical, even at both cathode and anode extremes (or around high abundant protein regions pI 5-7). To further evaluate the compatibility of this method with MS, protein spots were randomly excised from width and breadth of 2D-IEF gels for nano-LC-MS/MS analysis from both $Z$. muelleri and P. australis. All the selected protein spots indicated by circles and marked with numbers (Figures 3B, 4B) were

TABLE 1 | Protein yield, protein spot numbers on 2DE and extraction process time in the four tested protein extraction methods.

\begin{tabular}{lcccc}
\hline Method & \multicolumn{2}{c}{ Protein yield $(\mathbf{m g} / \mathbf{g ~ f w})$} & \multicolumn{2}{c}{ Spot number $(\mathbf{p l ~ 3 - 1 0 )}$} \\
\cline { 2 - 4 } & Z. muelleri & $\boldsymbol{P . ~ a u s t r a l i s}$ & Z. muelleri & P. australis \\
\hline P & $0.30 \pm 0.05$ & $0.93 \pm 0.09$ & $183 \pm 22$ & $641 \pm 33$ \\
TASP & $0.41 \pm 0.07$ & $0.80 \pm 0.11$ & $255 \pm 25$ & $684 \pm 23$ \\
BPP & $0.58 \pm 0.04$ & $0.90 \pm 0.10$ & $360 \pm 19$ & $777 \pm 28$ \\
M-BPP & $0.79 \pm 0.08$ & $1.02 \pm 0.08$ & $503 \pm 18(814 \pm 30)$ & $898 \pm 39(1082 \pm 36)$ \\
\hline
\end{tabular}

Values in 0 represent protein spots number on pl 5-8. 


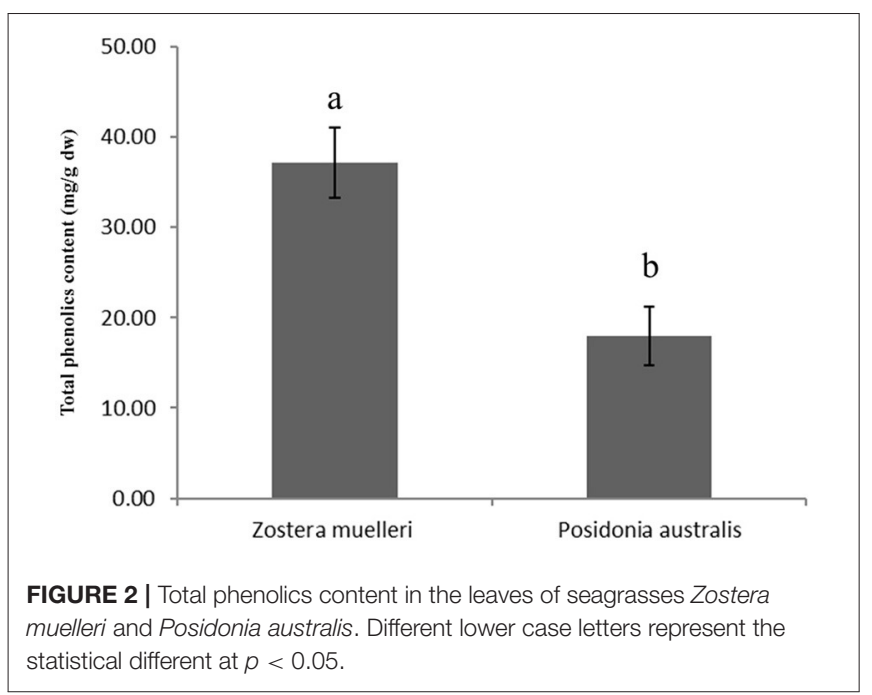

successfully analyzed by nano-LCMS/MS, identified, and listed in Tables 2, 3. Among the analyzed proteins, spot 6 for $Z$. muelleri (Figure 3B) and spot 2 for $P$. australis (Figure 4B) were randomly chosen to demonstrate their identification in detail. The peptide sequences translated from the cDNA sequences (Figures 3, 4A), annotated peptide mass spectrum (Figures 3, 4C), ion match summary (Figures 3, 4D), annotated top 10 peptide match description (Figures 3, 4E) were demonstrated for selected spots in both seagrasses. The functional classification of these selected proteins belonging to diverse biological, metabolic and cellular processes from both the seagrasses is presented in Figure 5. Finally, we successfully immunoblotted the phosphoenolpyruvate carboxylase (PEPC-a key enzyme in carbon metabolism) in the whole protein of $Z$. muelleri extracted using M-BPP method. We could detect this protein efficiently while using a minimum of $5 \mu \mathrm{g}$ of total protein (Figure 6).

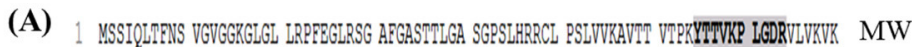

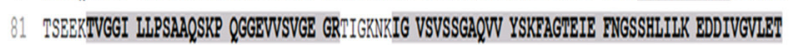

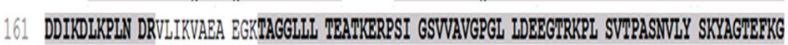
241 VDGSDYIVLR APDVIAVLA
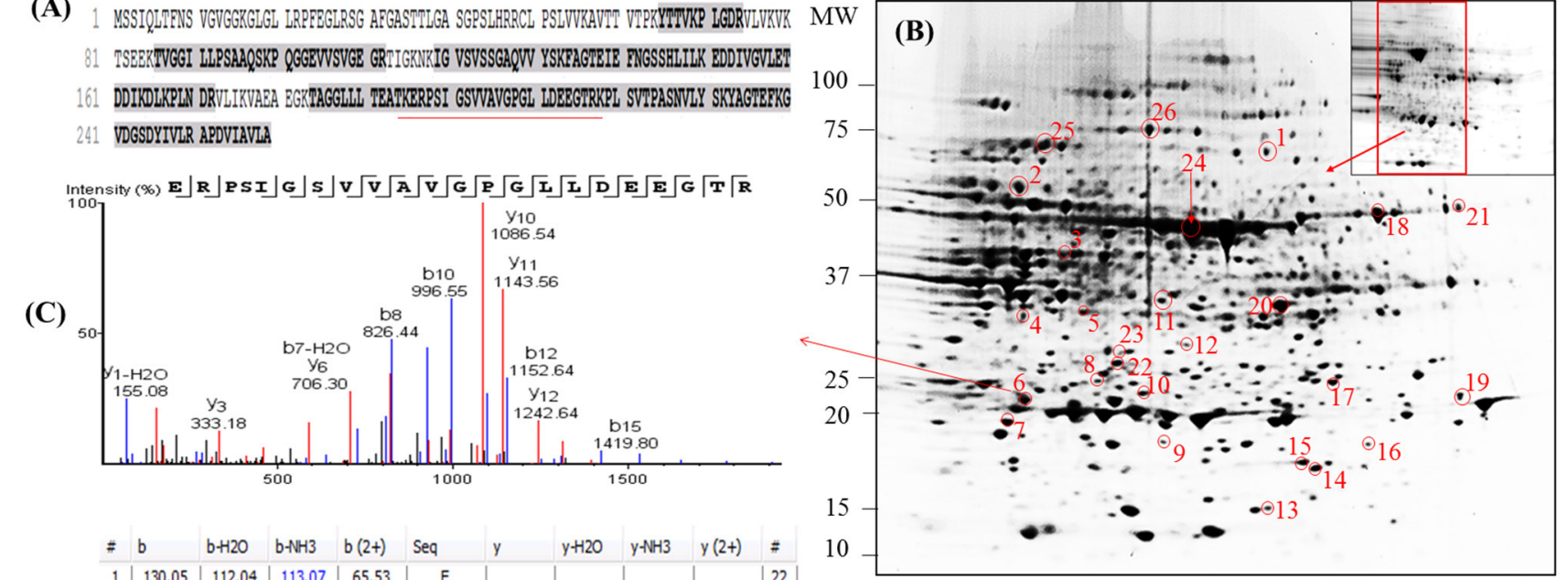

\begin{tabular}{|c|c|c|c|c|c|c|c|c|c|c|}
\hline & b & b-H2O & $\mathrm{NH} 3$ & $b(2 t)$ & Seq & $y$ & $y+\mathrm{H}_{2} \mathrm{O}$ & $y-N H 3$ & $y(2+)$ & \\
\hline 1 & 130.05 & 112.04 & 113.07 & 65.53 & $E$ & & & & & 22 \\
\hline 2 & 286.15 & 8.14 & 9.13 & 3.58 & & & 91.12 & & & 21 \\
\hline 3 & 383.20 & 19 & & 2.10 & & 03 & 35.02 & .00 & 77.01 & \\
\hline 4 & 470.24 & 452.23 & 453.21 & 235.62 & & 55.98 & 37.97 & 338.95 & 28.49 & \\
\hline 5 & 583.32 & 565.32 & 566.29 & 292.16 & & 68.94 & 1750.93 & 751.92 & 84.97 & 10 \\
\hline 6 & 640.34 & 2.33 & 623.31 & 320.67 & & 55.86 & 1637.85 & 638.83 & 28.43 & 17 \\
\hline 7 & 727.37 & 709.36 & 710.35 & 364.19 & & 598.84 & 1580.83 & 1581.81 & 799.92 & 16 \\
\hline 8 & 826.44 & 8.42 & 809.42 & 413.72 & & 81 & 1493.80 & & 40 & 15 \\
\hline 9 & 925.51 & 7.50 & 908.48 & 463.26 & & 69 & 1394.65 & & 706.87 & 14 \\
\hline 10 & 996.55 & 8.48 & 979.56 & 498.77 & & 67 & 1295.75 & 296.62 & 33 & 13 \\
\hline 11 & 1095.61 & 77.61 & 1078.59 & 548.31 & & 1242.64 & 1224.66 & 1225.55 & 621.82 & 12 \\
\hline 12 & 152.64 & 34.62 & 1135.61 & 576.82 & & 43.56 & 1125.64 & 1126.57 & 72.28 & 11 \\
\hline 13 & 1249.68 & 31.68 & 1232.66 & 625.35 & & 1086.54 & 1068.62 & 1069.54 & 543.77 & 10 \\
\hline 14 & 1306.70 & 1288.75 & 1289.68 & 653.86 & & 989.49 & 971.49 & & 95.24 & \\
\hline 15 & 1419.80 & 01.79 & 1402.77 & 710.40 & & & 14.46 & & 466.73 & \\
\hline 16 & 1532.87 & 14.87 & 1515.85 & 766.94 & & 819.38 & 801.38 & 02.36 & 410.27 & \\
\hline 17 & 1647.90 & 29.90 & 1630.88 & 824.45 & & 706.30 & 688.29 & 689.28 & 353.65 & 0 \\
\hline 18 & 1776.96 & 1758.94 & 1759.92 & 888.97 & & 591.27 & 573.26 & 74.25 & 296.14 & 5 \\
\hline 19 & 1906.00 & 1887.98 & 1888.97 & 953.50 & & 462.23 & 444.22 & 445.27 & 231.62 & 4 \\
\hline 20 & 1963.01 & 1945.00 & 1945.99 & 982.01 & & 333.18 & 315.19 & 316.16 & 167.08 & 3 \\
\hline 21 & 2064.06 & 2046.05 & 2047.03 & 1032.53 & 1 & 276.17 & 258.16 & 259.13 & 138.58 & \\
\hline 22 & & & & & R & 175.11 & 157.10 & 158.09 & 88.06 & 1 \\
\hline
\end{tabular}

\section{(E)}

\begin{tabular}{|c|c|c|c|c|c|c|c|c|c|}
\hline Peotde & $1009+$ & Nass & lenghth & $m$ & $\mathrm{~m} / \mathrm{z}$ & RT & Ned & $\operatorname{sen}$ & $\operatorname{sinec}$ \\
\hline 1. EPS:GSWAVPCLIDECTR & 73.65 & 2337.1650 & 22 & 4.8 & 75.7284 & 25.42 & 46562 & 16822 & 2 \\
\hline 2 RALSTPASMYYSK & 69.83 & 16028881 & 15 & 3.8 & 8024594 & 23.54 & 1.1 .23 & 16466 & 8 \\
\hline 3 CGGGGGYGSGGSSICSGGGSTCSGGGGGGGR & 66.13 & 2022946 & 31 & 3.9 & 795,3252 & 18.16 & $1.28 E 1$ & 14790 & 2 \\
\hline 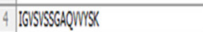 & 65.40 & 1479,7932 & 15 & 4.5 & 790.9072 & 23.75 & 6.992 & 16466 & 13 \\
\hline 5 GQVGCOIMEV(+15.99)DAPGIDSR & 65.23 & 200.9746 & 21 & 5.6 & 1055.5005 & 23.01 & 4.950 & 16276 & 1 \\
\hline 6 KPLSTPASN(+\$89) UYSK & 65.17 & 1603.8212 & 15 & 0.7 & 802949 & 23.31 & & 1632 & 2 \\
\hline 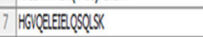 & 63.49 & 1836.9581 & 16 & 6.0 & 919.4919 & 25.45 & $3,45 E !$ & 16828 & $!$ \\
\hline 8 TAGQUIITATK & 61.11 & 1173.6005 & 12 & 4110 & 587,8311 & 24.58 & 4.2252 & 16634 & 5 \\
\hline 9 THUEYFESFDNR & 60.22 & 19926964 & 16 & 4.4 & 997,4876 & 26.39 & 4.21100 & 17031 & $!$ \\
\hline 10 ETIEDNEEQ:SSTK & 59.20 & 1995.9636 & 17 & .3 .5 & 998.9856 & 25.21 & $385 E 1$ & 16776 & 1 \\
\hline
\end{tabular}

FIGURE 3 | Demonstrative example for the identification of proteins extracted from leaves of seagrass Zostera muelleri. The protein spot (spot 6) was excised, trypsin digested and analyzed using nanoLC-MS/MS. The peptide sequences translated from the CDNA sequences (A), 2D-IEF of proteins resolved on pl range 5-8 (B), annotated peptide mass spectrum (C), ion match summary (D), top 10 annotated peptide with high -10logP score (E) are demonstrated for selected spots. Randomly excised protein spots are encircled red and marked with their corresponding numbers. The protein sequences marked with dark letters represent the matched peptides. The matched peptides marked with red under-line was identified and analyzed by nanoLC-MS/MS. The blue and red marked values in ion match summary (D) represent the identified and matched amino acids from $\mathrm{N}$ - and C-terminal of a peptide sequence. 
A 1 MASHIVGYPR MGPRRELKRA LESFWDGKSS ADDLQKVASD LRSSINRQMS EAGIKYIPSN TESYYDQVLD TTAVLGAVPT 81 RYGWNGGEIG EDTFFSMARG NATLPAMEMI KWFDTNYHFI VPELSPDTSF AYSSHRAVSE YKEAKEIGID TVPVLIGPVS

161 YLLLSKPARG VEKSFSPLSL LEIVLPVYKE VINELKAaGA SWIQFDEPTI IKDLDSAQLD AFTKAYADLE SSCAGLNVLI

241 ETYFADVTPE AEKTITSLKG VTAYGPDIVR GAKTMDLIKS DFPADKYLPA GVDDGRIINA NNLASSMTTL SSLESIVGKD

321 RIVWSTSCSL LHTAVDLINE TKLDSEIKSW LAFASQKIVE VNALAKALDG QRDEAFTSAN AAAQASRRSS PRVNNAEVQQ

401 AASALRGSDH RRSTDVSSRL DAQQRKLNLP ILPTTTIGSF PQIVELRRTR REYKARKISE EAYISAMKEE ISKVVRLQEE

481 LDIDVLVEG PERNDMVEYF GEQLSGEAFS ANGWVQSYGS RCVKPPIIYG DVSRPKPMTV FWSSNAQSMT ARPMKGMLTC

561 PVIILNWSFV RDDQPRFETC YQIALAIKKE VEDLEAAGIN VIQIDEAALR BGCPIRRSEV AFYLEWAVHS FRITNCGVKD

641 TTQIHTHMCY SNENDIIHSI INMDADVITI ENSRSDEKLL SVRREGVRYG AGIGPGYYDI HSPRIPTTEE IADRINKMLA

721 VLETNILWVN PDCGLKTRKY SEVKPALTNV VAAAKRLRTE LASAR
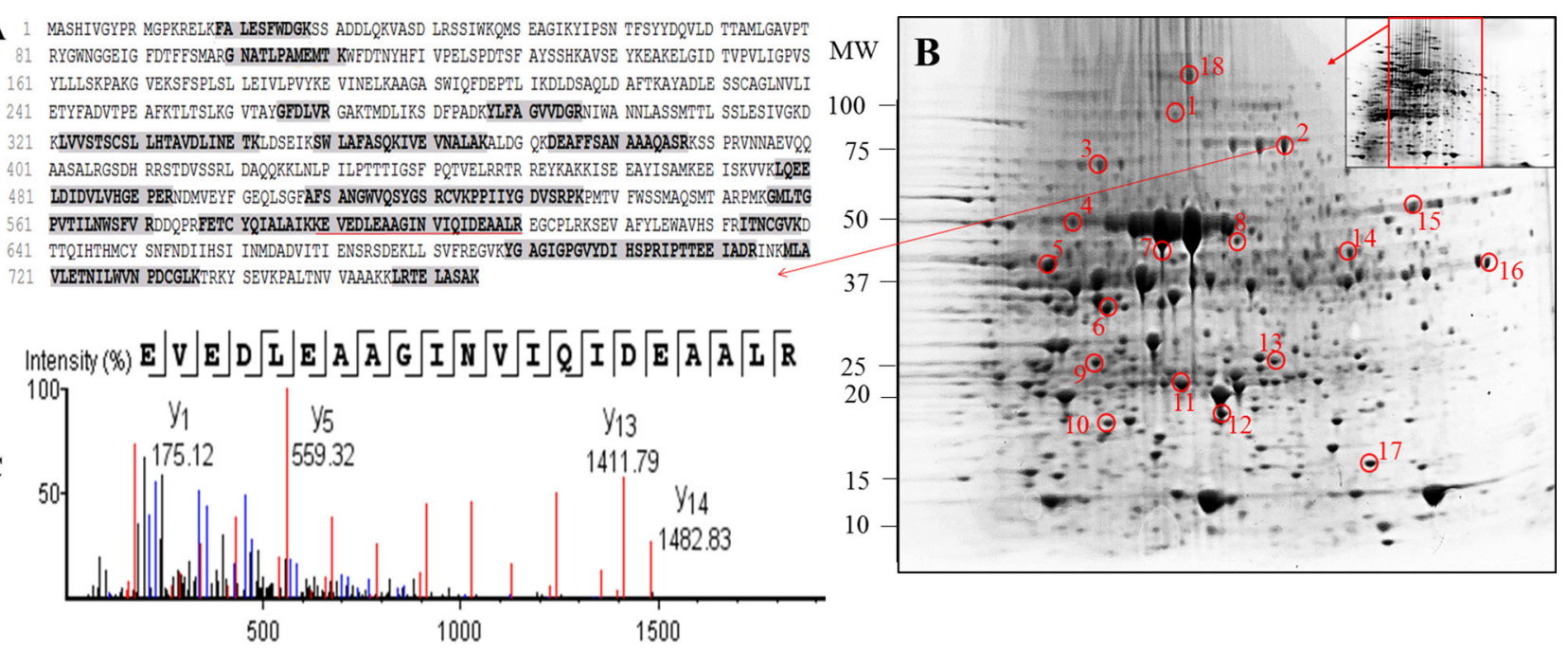

$\mathbf{E}$

\begin{tabular}{|c|c|c|c|c|c|c|c|c|c|c|}
\hline \# & b & $\mathrm{b}+\mathrm{H}_{2} \mathrm{O}$ & b-NH3 & $b(2+)$ & Seq & $y$ & $y+120$ & $y-\mathrm{NH} 3$ & $y(2+)$ & \# \\
\hline 1 & 130.05 & 112.08 & 113.02 & 65.53 & $E$ & & & & & 21 \\
\hline 2 & 229.12 & 211.11 & 212.09 & 115.06 & V & 2139.13 & 2121.12 & 2122.10 & 1070.06 & 20 \\
\hline 3 & 358.16 & 340.15 & 341.21 & 179.58 & $E$ & 2040.06 & 2022.05 & 2023.03 & 1020.53 & 19 \\
\hline 4 & 473.19 & 455.18 & 456.16 & 237.09 & D & 1911.02 & 1893.01 & 1893.99 & 956.01 & 18 \\
\hline 5 & 586.27 & 568.26 & 569.25 & 293.64 & L & 1795.99 & 1777.98 & 1778.96 & 898.47 & 17 \\
\hline 6 & 715.33 & 697.32 & 698.29 & 358.16 & $E$ & 1682.91 & 1664.90 & 1665.88 & 841.95 & 16 \\
\hline 7 & 786.37 & 768.34 & 769.38 & 393.68 & A & 1553.86 & 1535.85 & 1536.84 & 777.43 & 15 \\
\hline 8 & 857.39 & 839.38 & 840.36 & 429.20 & A & 1482.83 & 1464.82 & 1465.80 & 741.91 & 14 \\
\hline 9 & 914.42 & 896.46 & 897.46 & 457.71 & G & 1411.79 & 1393.78 & 1394.76 & 706.40 & 13 \\
\hline 10 & 1027.52 & 1009.48 & 1010.57 & 514.25 & I & 1354.77 & 1336.68 & 1337.74 & 677.88 & 12 \\
\hline 11 & 1141.54 & 1123.53 & 1124.58 & 571.27 & $\mathrm{~N}$ & 1241.69 & 1223.67 & 1224.66 & 621.27 & 11 \\
\hline 12 & 1240.60 & 1222.62 & 1223.58 & 620.80 & V & 1127.66 & 1109.63 & 1110.61 & 564.32 & 10 \\
\hline 13 & 1353.61 & 1335.68 & 1336.68 & 677.35 & I & 1028.58 & 1010.57 & 1011.55 & 514.79 & 9 \\
\hline 14 & 1481.75 & 1463.74 & 1464.72 & 741.37 & Q & 915.49 & 897.46 & 898.47 & 458.24 & 8 \\
\hline 15 & 1594.83 & 1576.82 & 1577.81 & 797.92 & I & 787.43 & 769.38 & 770.41 & 394.22 & 7 \\
\hline 16 & 1709.86 & 1691.85 & 1692.83 & 855.43 & D & 674.35 & 656.34 & 657.32 & 337.67 & 6 \\
\hline 17 & 1838.90 & 1820.89 & 1821.88 & 919.95 & $E$ & 559.32 & 541.31 & 542.29 & 280.16 & 5 \\
\hline 18 & 1909.94 & 1891.93 & 1892.91 & 955.47 & A & 430.27 & 412.21 & 413.23 & 215.64 & 4 \\
\hline 19 & 1980.98 & 1962.97 & 1963.95 & 990.99 & A & 359.24 & 341.21 & 342.21 & 180.12 & 3 \\
\hline 20 & 2094.06 & 2076.05 & 2077.03 & 1047.53 & L & 288.20 & 270.19 & 271.17 & 144.60 & 2 \\
\hline 21 & & & & & $R$ & 175.12 & 157.11 & 158.09 & 88.06 & 1 \\
\hline
\end{tabular}

\begin{tabular}{|c|c|c|c|c|c|c|c|c|c|}
\hline Pepotce & $.1009 \downarrow$ & Nass & length & $\mathrm{ppm}$ & $\mathrm{m} / \mathrm{2}$ & RT & Ared & Sean & sspect \\
\hline BEVEAGMOMODEALR & 6241 & 267.1646 & 21 & 3.5 & 11345935 & 25.57 & 2.233 & 16046 & 1 \\
\hline ALGQ $(+98)$ OESFFSAULAQQASR & 57,02 & 21240.0234 & 21 & 12.7 & 10630.0225 & 22.9 & 2.622 & 15411. & 2 \\
\hline EEDLEAGMMO(+.98)]DEALR & 96.83 & 2688.1484 & 21 & 3.5 & 1135,0054 & 25.75 & & 16064 & 1 \\
\hline YGGGGGGMOHSPR & 55.68 & 165782212 & 16 & 3.8 & 829.9210 & 22.41 & 2.7953 & 15327 & 6 \\
\hline 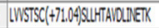 & 55.23 & 2313.2551 & 21 & 4.9 & 720061 & 25.76 & 8.7122 & 16006 & 1 \\
\hline KGELEAAGMMODEAMR & 53.59 & 2395.2593 & 22 & 15.8 & 799.436 & 25.20 & $6.55 !$ & 15987 & 1 \\
\hline LGATDUEOEOPJUAK & 51.94 & 2210.0987 & 20 & 5.3 & 1.106 .6615 & 24.19 & 3.253 & 15728 & 2 \\
\hline ALGQQOEAFFANAAQASR & 50,96 & 21230036 & 21 & 8.3 & 708.6900 & 22.51 & 1.942 & 15350 & 2 \\
\hline LQEADDVVWKGEER & 49.41 & 1990.0007 & 17 & 5.5 & 996.0131 & 24.73 & 2.263 & 15858 & 2 \\
\hline 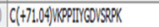 & 49.19 & 1744.9540 & 15 & 10.3 & 581.6649 & 21.93 & 7,662 & 15214 & 4 \\
\hline CGSGGGGSISGGGOGSGGGSGGGR & 48.88 & 1790.7411 & 23 & 6.9 & 871.3838 & 16.24 & $3,31 \mathrm{E} 1$ & 13200 & 1 \\
\hline
\end{tabular}

FIGURE 4 | Demonstrative example for the identification of proteins extracted from leaves of seagrass Posidonia australis. The protein spot (spot 2) was excised, trypsin digested and analyzed using nanoLC-MS/MS. The peptide sequences translated from the CDNA sequences (A), 2D-IEF of proteins resolved on pl range 5-8 (B), annotated peptide mass spectrum (C), ion match summary (D), top 10 annotated peptide with high -10logP score (E) are demonstrated for selected spots. Randomly excised protein spots are encircled red and marked with their corresponding numbers. The protein sequences marked with dark letters represent the matched peptides. The matched peptides marked with red under-line was identified and analyzed by nanoLC-MS/MS. The blue and red marked values in ion match summary (D) represent the identified and matched amino acids from $\mathrm{N}$ - and C-terminal of a peptide sequence.

\section{DISCUSSION}

In marine macrophytes, proteomics-based approaches are still in the incipient stage for use in understanding the acclimation and/or tolerance mechanisms to environmental cues. Marine macrophyte protein extraction is particularly difficult due to low protein concentrations and contaminant co-extraction. Due to this, a specific protein extraction protocol needs to be optimized and established for extracting the maximum amount and range of proteoform species in an unbiased manner, not favoring particular proteins while leaving others behind and insoluble. Toward this, protein extraction protocols have been refined to produce well-resolved 1-D and/or 2-D PAGE images in seagrass Posidonia oceanica (Migliore et al., 2007; Spadafora et al., 2008; Mazzuca et al., 2009; Dattolo et al., 2013) and Cymodocea nodosa (Piro et al., 2015). These studies utilized the universal protein extraction protocol wherein protein is precipitated in TCA and 2-ME in cold acetone, followed by several rinsing steps with $2-\mathrm{ME}$ in cold acetone and finally, resuspension of the dry pellet in a buffer optimized for IPG strips. Considering their positive results, we tested phenol (Wu et al., 2014a) and the universal method (which is based on TCA-acetone-SDS-Phenol extraction; Wu et al., 2014b) for protein extraction in Z. muelleri. This method provided poor results on 2D-IEF when applied to Z. muelleri leaves (Supplementary Figures 1A,B), however worked well with $P$. australis, suggested that the protocol for protein extraction is plant and species-specific. Subsequently, we explored the BPP method of protein extraction which has been successfully employed in the halophytes Salicornia europaea (Wang et al., 2007), Thellungiella halophile (Wang et al., 2013), and Sesuvium portulacastrum (Yi et al., 2014). The BPP method was comparatively better in terms of higher protein yield and 
TABLE 2 | Identification of proteins using software PEAKS studio ver 8.0 analyzed by LC-MS/MS for Zostera muelleri.

\begin{tabular}{|c|c|c|c|c|c|c|c|c|c|c|c|c|}
\hline \multirow[t]{2}{*}{ Spot no } & \multirow[t]{2}{*}{ Protein name } & \multirow[t]{2}{*}{ Accession } & \multirow[t]{2}{*}{ Organism } & \multirow[t]{2}{*}{ SLa } & \multicolumn{2}{|c|}{ pl } & \multicolumn{2}{|c|}{ Mr } & \multirow[t]{2}{*}{ Score } & \multirow[t]{2}{*}{ Pep $^{b}$} & \multirow[t]{2}{*}{ Unic } & \multirow[t]{2}{*}{ SC } \\
\hline & & & & & Obs. & Thr. & Obs. & Thr. & & & & \\
\hline 1 & Heat shock protein STI1 & gb|KMZ64384.1 & Z. marina & $\mathrm{N}$ & 6.78 & 5.79 & 75.69 & 65.94 & 192.68 & 17 & 17 & 35 \\
\hline 2 & Inositol-3-phosphate synthase & gb|KMZ57169.1 & Z. marina & CY & 5.72 & 5.84 & 64.78 & 64.95 & 169.57 & 14 & 7 & 28 \\
\hline 3 & Phosphoglycerate kinase & gb|KMZ64101.1 & Z. marina & CL & 6.12 & 8.30 & 45.68 & 50.32 & 205.37 & 33 & 26 & 77 \\
\hline 4 & Isoflavone reductase-like protein & gb|KMZ72723.1 & Z. marina & CY & 5.73 & 5.13 & 35.69 & 35.23 & 103.15 & 7 & 7 & 25 \\
\hline 5 & Enoyl-ACP Reductase & gb|KMZ61785.1 & Z. marina & $\mathrm{CL}$ & 6.09 & 8.69 & 36.28 & 39.88 & 161.88 & 12 & 4 & 40 \\
\hline 6 & 20 kDa chaperonin & gb|KMZ69941.1 & Z. marina & $\mathrm{CL}$ & 5.88 & 8.49 & 24.87 & 27.09 & 213.37 & 22 & 20 & 64 \\
\hline 7 & ATP synthase delta-subunit & gb|KMZ66253.1 & Z. marina & M & 5.77 & 9.37 & 21.92 & 28.13 & 182.27 & 15 & 6 & 81 \\
\hline 8 & Protein thf1 & gb|KMZ63330.1 & Z. marina & $\mathrm{CL}$ & 6.16 & 8.87 & 26.23 & 33.20 & 154.37 & 9 & 7 & 41 \\
\hline 9 & Glutathione S-transferase F9, Phi class & gb|KMZ60880.1 & Z. marina & CY & 6.40 & 5.46 & 19.14 & 23.92 & 147.20 & 14 & 14 & 63 \\
\hline 10 & Ribosome-recycling factor & gb|KMZ64562.1 & Z. marina & $\mathrm{CL}$ & 6.32 & 9.16 & 26.02 & 30.96 & 108.74 & 5 & 5 & 32 \\
\hline 11 & Quinone oxidoreductase-like protein & gb|KMZ66757.1 & Z. marina & $\mathrm{CL}$ & 6.38 & 7.66 & 35.83 & 37.99 & 162.25 & 11 & 11 & 49 \\
\hline 12 & Phage shock protein A, PspA & gb|KMZ69686.1 & Z. marina & $\mathrm{CL}$ & 6.47 & 8.99 & 30.14 & 39.93 & 150.97 & 13 & 13 & 49 \\
\hline 13 & hypothetical protein & gb|KMZ71315.1 & Z. marina & $\mathrm{CL}$ & 6.81 & 9.22 & 15.96 & 15.25 & 64.81 & 2 & 2 & 15 \\
\hline 14 & PsbP-like protein 1 & gb|KMZ62962.1 & Z. marina & $\mathrm{CL}$ & 6.98 & 9.22 & 17.86 & 28.18 & 168.68 & 11 & 11 & 66 \\
\hline 15 & Adenine nucleotide alpha hydrolases like & gb|KMZ58089.1 & Z. marina & $\mathrm{CL} / \mathrm{N}$ & 6.93 & 5.63 & 18.16 & 18.38 & 137.32 & 8 & 8 & 57 \\
\hline 16 & Nascent polypeptide-associated complex, $\beta$ & gb|KMZ60575.1 & Z. marina & $\mathrm{N}$ & 7.18 & 7.92 & 19.05 & 16.35 & 106.41 & 6 & 6 & 51 \\
\hline 17 & ATP synthase subunit $O$, mitochondrial & gb|KMZ64579.1 & Z. marina & M & 7.05 & 9.08 & 26.02 & 30.50 & 128.56 & 6 & 6 & 32 \\
\hline 18 & Protein plastid transcriptionally active 16 & gb|KMZ73091.1 & Z. marina & $\mathrm{N}$ & 7.22 & 8.98 & 53.86 & 53.98 & 215.51 & 30 & 6 & 60 \\
\hline 19 & OEE-PsbP & gb|KMZ57551.1 & Z. marina & $\mathrm{M}$ & 7.53 & 8.76 & 23.18 & 27.68 & 200.20 & 13 & 11 & 36 \\
\hline 20 & Malate dehydrogenase & gb|KMZ65591.1 & Z. marina & M & 6.85 & 8.23 & 35.59 & 36.61 & 210.24 & 22 & 6 & 67 \\
\hline 21 & Glycine hydroxymethyltransferase & gb|KMZ69888.1 & Z. marina & M & 7.51 & 8.79 & 55.52 & 57.82 & 185.66 & 24 & 24 & 62 \\
\hline 22 & Plasma membrane associated cation-binding protein 1 & gb|KMZ61692.1 & Z. marina & CL & 6.23 & 5.59 & 28.02 & 21.60 & 142.10 & 14 & 14 & 64 \\
\hline 23 & Proteasome subunit alpha type- 6 & XP_010937324.1 & Z. marina & $\mathrm{N}$ & 6.25 & 6.00 & 29.37 & 27.42 & 110.29 & 9 & 5 & 49 \\
\hline 24 & RuBisCo, large subunit, partial & gb|AlZ98377.1 & Z. angustifolia & $\mathrm{CL}$ & 6.51 & 6.09 & 48.84 & 50.21 & 209.26 & 24 & 0 & 56 \\
\hline 25 & Transketolase & gb|KMZ75731.1 & Z. marina & $\mathrm{CL}$ & 5.94 & 5.93 & 78.87 & 81.03 & 282.02 & 43 & 17 & 69 \\
\hline 26 & Methionine synthase & gb|KMZ76082.1 & Z. marina & $\mathrm{CL}$ & 6.32 & 5.92 & 84.59 & 84.67 & 306.50 & 34 & 10 & 53 \\
\hline
\end{tabular}

a Subcellular location of proteins was predicted using the online Plant-mPLoc server (http://www.csbio.sjtu.edu.cn/ bioinf/ plant-multi);

${ }^{b}$ Exclusive unique peptide count:

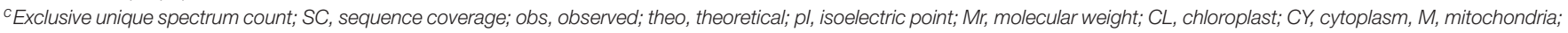
$\mathrm{N}$, nucleus; methionine synthase, 5-methyltetrahydropteroyltriglutamate-homocysteine S-methyltransferase; OEE-Oxygen evolving enhancer protein.

number of visible protein spots for $Z$. muelleri leaf samples resolved on 2D-IEF using 3-10 IPG strips. Therefore, we decided to further modify the BPP method as described to define a protocol better suited to $Z$. muelleri.

Interestingly, the M-BPP method resulted in 40 and $15 \%$ higher number of protein spots when compared to the original BPP protein extraction method in Z. muelleri and $P$. australis, respectively. Moreover, the M-BPP method for protein extraction, like the BPP method, was completed in just half of the time it takes for the TASP method, which is a significant outcome considering the protein yield, number of spots and minimal background staining observed on the $2 \mathrm{D}$ gels. To the best of our knowledge, this is the first report on extracting the protein from seagrasses using BPP based extraction protocols. However, historically, TCA/acetone/Phenol based protein extraction methods have been employed in the seagrasses P. oceanica (Spadafora et al., 2008; Dattolo et al., 2013) and C. nodosa (Piro et al., 2015) exposed to abiotic stresses. Spadafora et al. (2008) demonstrated the 2DE based proteome profiling in the juvenile, intermediate and adult leaves in $P$. oceanica, revealing mainly abundant proteins as detectable, while less abundant proteins that could be differentially expressed among the studied tissues were hard to identify. There is only a single report in $P$. oceanica wherein a $2 \mathrm{D}$-PAGE based proteomic approach was employed to address the low light acclimation response with detection of $>2,600$ protein spots on 2D-PAGE from leaf tissues, however only 26 proteins were shown to be differentially expressed in low-light conditions. Among the differentially regulated proteins, $<50 \%$ proteins were identified through mass spectrometry analyses, however others could not be identified due to lack of significant genomic and proteomic database for Posidonia sp. (Mazzuca et al., 2009). Proteome profiling in seagrasses has subsequently been performed using labeled free 1-DE followed by MALDI-TOF based semiquantitative analysis to study their stress response to altered light and salinity conditions (Dattolo et al., 2013; Piro et al., 2015).

The lower protein yield obtained with the $\mathrm{P}$ and TASP methods when applied to $Z$. muelleri in contrast to the yield from $P$. australis could be due to a less efficient removal of polyphenolic compounds and other interfering substances including complex 
TABLE 3 | Identification of proteins using software PEAKS studio ver 8.0 analyzed by LC-MS/MS for Posidonia australis.

\begin{tabular}{|c|c|c|c|c|c|c|c|c|c|c|c|c|}
\hline $\begin{array}{l}\text { Spot } \\
\text { no }\end{array}$ & Protein name & Accession & Organism & $\mathbf{S L}^{\mathrm{a}}$ & \multicolumn{2}{|c|}{ pl } & \multicolumn{2}{|c|}{$\mathrm{Mr}$} & Score & Pep $^{b}$ & $U_{n i}{ }^{c}$ & SC \\
\hline 2 & Methionine synthase & gb|KMZ76082.1 & Z. marina & $\mathrm{CL}$ & 6.95 & 5.92 & 85.86 & 84.67 & 185.22 & 20 & 1 & 32 \\
\hline 3 & Transketolase & gb|KMZ75731.1 & Z. marina & $\mathrm{CL}$ & 6.23 & 5.93 & 74.17 & 81.02 & 115.73 & 5 & 1 & 9 \\
\hline 4 & Adenosylhomocysteinase & gb|KMZ66813.1 & Z. marina & PX & 6.14 & 5.60 & 49.83 & 53.56 & 128.50 & 15 & 7 & 21 \\
\hline 7 & GDP-mannose 3,5-epimerase 1 & gb|KMZ73857.1 & Z. marina & GB & 6.48 & 5.57 & 44.73 & 42.80 & 209.27 & 18 & 1 & 45 \\
\hline 8 & Isocitrate dehydrogenase (NADP(+)) & gb|KMZ71727.1 & Z. marina & $\mathrm{CL} / \mathrm{CY} / \mathrm{M} / \mathrm{PX}$ & 6.77 & 5.81 & 48.32 & 50.21 & 149.10 & 13 & 4 & 29 \\
\hline 9 & Probable ATP synthase 24 kDa subunit, & ref|XP_008791367.1 & P. dactylifera & M & 6.21 & 7.74 & 27.82 & 28.02 & 68.78 & 2 & 2 & 24 \\
\hline 10 & Rhodanese-like domain-containing protein 14 & ref|XP_002274646.1 & V. vinifera & $\mathrm{CL}$ & 6.26 & 9.00 & 18.55 & 25.92 & 117.24 & 6 & 6 & 33 \\
\hline 11 & Glutathione S-transferase F7, Phi class & gb|KMZ61632.1 & Z. marina & $\mathrm{CY}$ & 6.55 & 5.44 & 23.78 & 24.38 & 97.74 & 6 & 5 & 25 \\
\hline 16 & G3PDH & gb|KMZ64911.1 & Z. marina & $\mathrm{CY}$ & 7.72 & 6.97 & 41.55 & 36.47 & 119.45 & 7 & 2 & 23 \\
\hline 17 & Nucleoside diphosphate kinase 3-like & ref|XP_004244635.1 & S. lycopersicum & $\mathrm{CY} / \mathrm{CL} / \mathrm{M} / \mathrm{N}$ & 7.29 & 9.69 & 16.25 & 25.47 & 88.49 & 5 & 5 & 18 \\
\hline 18 & RuBisCO, large subunit & gb|AlZ98377.1 & Z. marina & $\mathrm{CL}$ & 6.61 & 6.09 & 120.18 & 50.21 & 109.89 & 7 & 0 & 34 \\
\hline
\end{tabular}

a Subcellular location of proteins was predicted using the online Plant-mPLoc server (http://www.csbio.sjtu.edu.cn/bioinf/plant-multi);

${ }^{b}$ Exclusive unique peptide count;

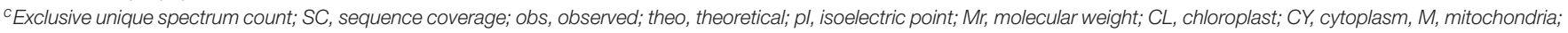

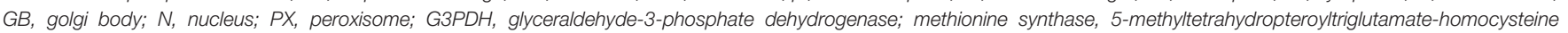
S-methyltransferase; A. thaliana, Arabidopsis thaliana; V. venifera, Vitis Vinifera; P. dactylifera, Phoenix dactylifera; Solanum lycopersicum, S. Iycopersicum.

cell wall polysaccharides and pigments. The coextraction of non-protein cellular components such as phenolics and polysaccharides adversely affects protein migration, resulting in streaking and smearing in 2D-PAGE with a reduction in the number of distinctly resolved protein spots (Wu et al., 2014a). In the present study, the quantitative analysis of total polyphenolic compounds in leaves exhibited a significantly higher level in $Z$. muelleri in contrast to $P$. australis. The low cellular proteins content (due to the presence of large vacuoles) and presence of high content of interfering compounds such as phenolics or complex polysaccharides could be a possible reason for not obtaining high quality 2D gels in $Z$. muelleri with these methods. Z. muelleri leaf tissues have been shown to rich in phenolic compounds like coumaric acid, cinnamic acid; flavanoids, as well as lignins, and carbohydrates (Kuzhiumparambil et al., in press). These compounds are known to form not only the hydrogen bonds with proteins but they also form irreversible complexes with proteins by oxidation and covalent condensation which leads to charge heterogeneity resulting in streaking of gels (Wu et al., 2014a). Further, co-extraction of carbohydrates blocks the gel pores causing precipitation and prolonged focusing time, which may also result in loss of protein spots and streaks in the gels (Carpentier et al., 2005). Ferrat et al. (2012) also demonstrated a significantly higher level of phenolics in the leaves of $Z$. marina in contrast to $P$. oceanica. Altogether, this suggest that M-BPP method was efficient in removing the polysaccharides and phenolics compared to P and TASP, thus resulted in 2DE gels with clear background and minimal streaking for $Z$. muelleri.
Further, TASP involves the TCA/acetone based precipitation which typically requires extensive washing until the protein pellet becomes colorless, which is time-consuming and results in the proteins having extended exposure to low $\mathrm{pH}$. This may lead to protein degradation or modifications (Wang $\mathrm{X}$. et al., 2016) as also observed in our present study with low number of protein spots on 2DE gels for Z. muelleri. Further, in the TASP method, salt ions should be somewhat eliminated during protein precipitation with TCA, however, the sample produced distinct horizontal streaks specifically for Z. muelleri proteins (Supplementary Figure 1B). Moreover, in the TASP method following protein precipitation, protein re-solubilization was difficult, necessitating solubilization using a sonication probe (3 times each with $5 \mathrm{~s}$ ) while keeping the protein sample cold. Similar to our findings, dissolution of proteins following precipitation was also found to be quite difficult in TCA based methods which could lead to a lower protein yield in different tissues of Cajanus cajan (Singh et al., 2015). However, in contrast to the TASP method in present study, the protein pellets obtained in the BPP and M-BPP methodologies were easily dissolved in solubilization buffer (UTC- Urea+Thiourea+ $\mathrm{CHAPS} / \mathrm{C} 7 \mathrm{BzO}$ ) in the present study. $\mathrm{C} 7 \mathrm{BzO}$ has previously been shown to solubilize more proteins from plant samples at a lower concentration than CHAPS (Luche et al., 2003).

In present study, the incorporation of an ionic detergent $(0.5 \%$ SDS) together with a non-ionic detergent (1.5\% Triton X-100), $2 \%$ PVPP and protease inhibitor cocktail into the extraction buffer of the M-BPP method appeared not only to increase the protein yield but also significantly reduced the interfering 

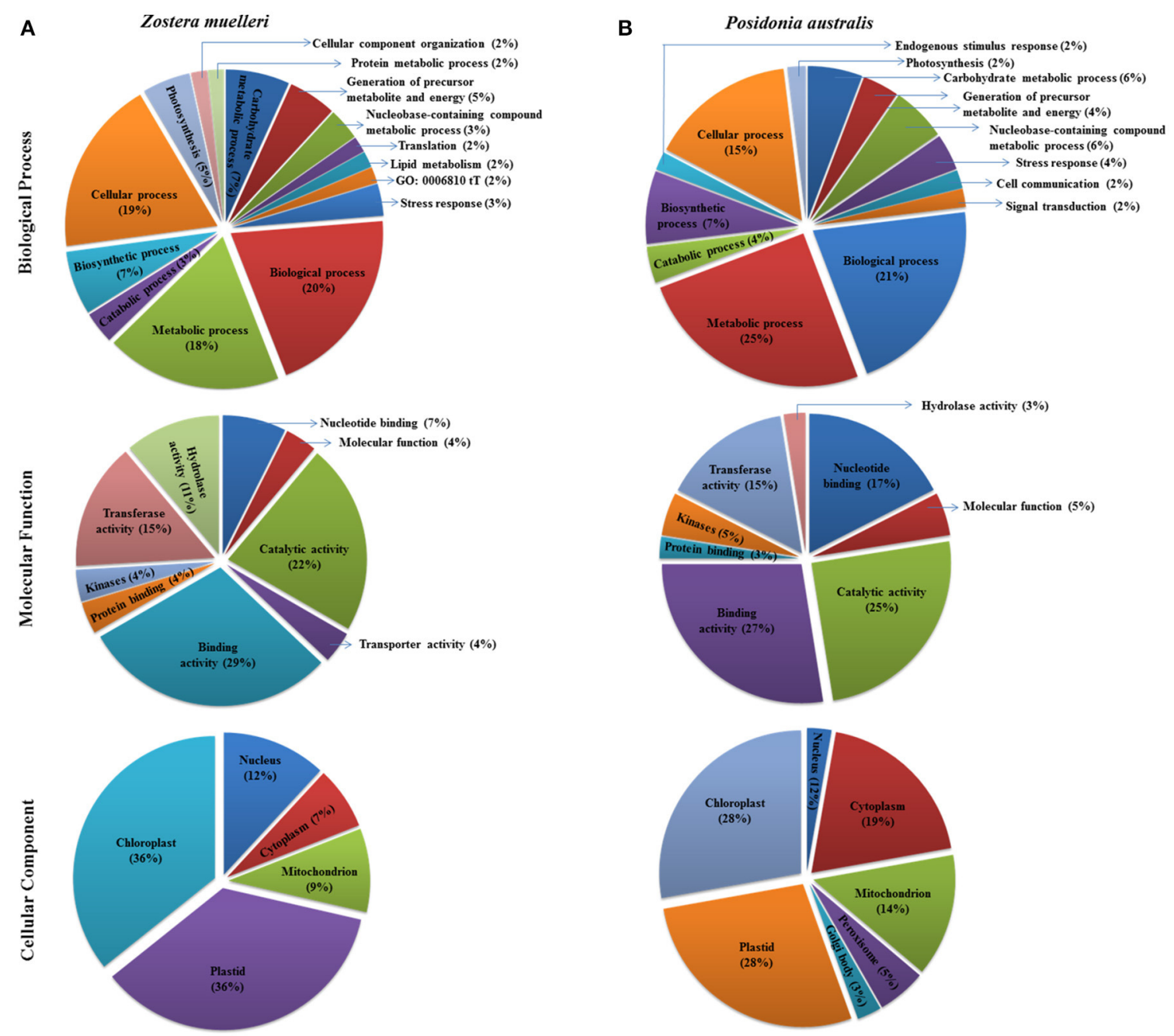

FIGURE 5 | Representation of functional classification of GO annotation distribution for the randomly chosen protein spots (red encircled spots shown in Figures $\mathbf{3}, \mathbf{4}$ ) categorized to diverse biological process, molecular function, and cellular component in seagrasses Zostera muelleri (A) and Posidonia australis (B).

substances while inhibiting the protease activity and preventing the protein degradation and phenolics oxidation. The presence of both ionic and non-ionic detergents in the M-BPP protein extraction buffer seemed efficient in breaking lipid-lipid and lipid-protein interactions, thereby isolating membrane proteins such as H+-transporting ATP synthase, plasma membrane intrinsic protein (PIP) aquaporins, and annexins (Vâlcu and Schlink, 2006). Incorporation of water-insoluble PVPP into the extraction buffer, which forms hydrogen bonds with phenolic compounds (1-15\%, depending on the content of polyphenolics and pectin content), has been suggested as the most efficient practice for the removal of phenolics from plant extracts (Isaacson et al., 2006). Incorporation of ascorbic acid, borax, PVPP, and $\beta$-mercaptoethanol into the protein extraction buffer have been previously suggested to extract storage proteins from the recalcitrant tissues of olive leaf (Garcia et al., 2000), from tropical trees (Tian et al., 2003) and halophytes (Wang et al., 2007, 2013; Yi et al., 2014) possibly by preventing the oxidization of polyphenol to polyquinones and the activity of many oxidizing enzymes under highly reduced conditions of the extraction buffer. Historically, BPP based protein extraction methods has been demonstrated as effective for the subcellular fractionation of laticifer latex in Hevea brasiliensis (Wang et al., 2010) and in the starch rich tuberous roots of Casava (Manihot esculenta; Wang D. et al., 2016) producing protein extracts compatible with 2-DE and MS.

The protein spots that were randomly excised from width and breadth of 2D-IEF gels obtained from M-BPP method for both $Z$. muelleri and P. australis, of protein solubilized in UTC7 prior to IEF were successfully analyzed by nanoLC-MS/MS analysis. Progress in the area of proteomics heavily relies on the development of analytical tools for the sensitive, selective, and high-throughput studies of protein analytes (Aebersold and Goodlett, 2001). MS has evolved into a primary analytical tool for proteomics research, especially when coupled with high resolution separation techniques, due to the high information content that can be derived from these coupled techniques (Aebersold and Mann, 2003). Advances 


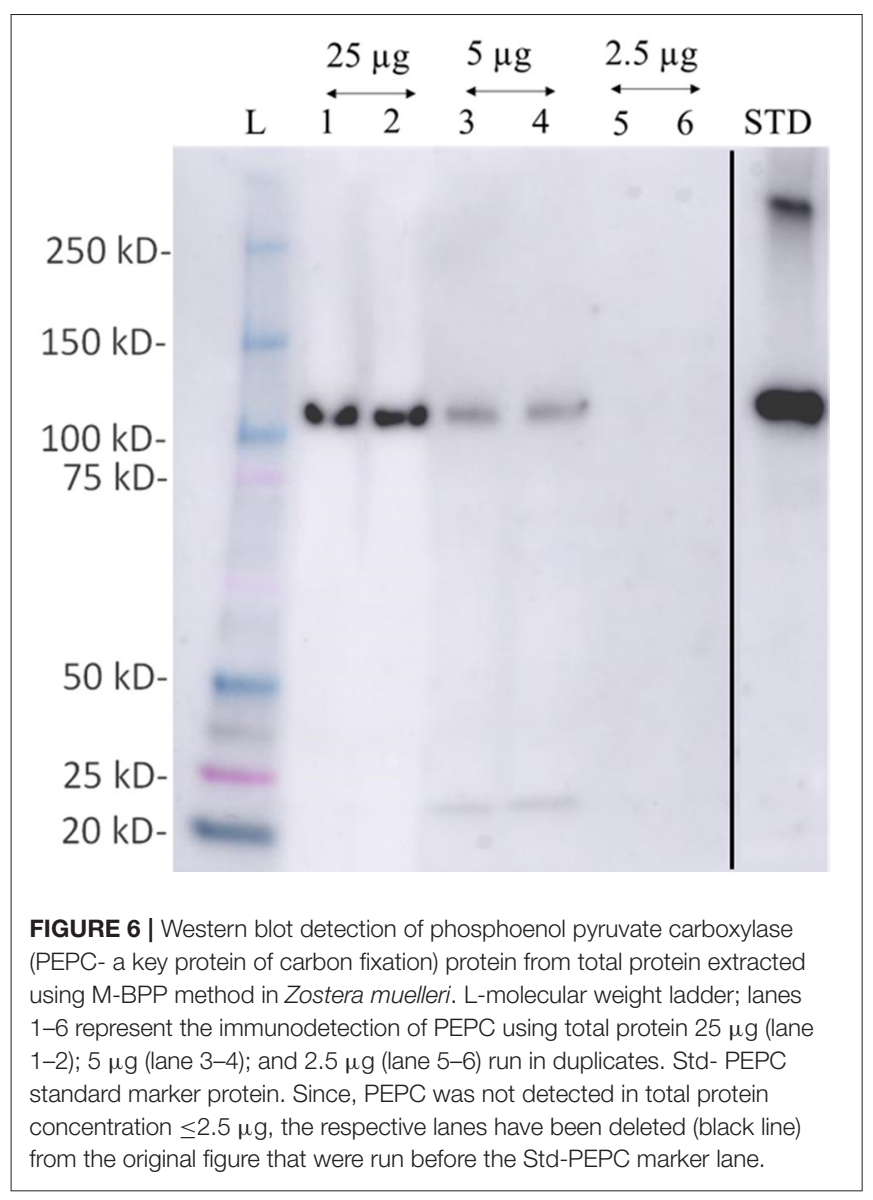

in MS have been substantially facilitated by two ionizations techniques; electrospray ionization (ESI) and matrix-assisted laser desorption/ionization (MALDI). ESI-MS produces highly charged ions directly from liquids and is therefore useful for coupling to liquid separations; however MALDI is fast and efficient and has a high tolerance to non-volatile buffers and impurities (Aebersold and Goodlett, 2001). Mass spectrometry enables unambiguous identification of proteins by accurate mass measurements of gas-phase protein and peptide ions and peptide fragment ions. ESI-MS linked to nanoliter-flow HPLC systems are preferred proteomic analytical platform in providing separation, mass determination, and amino acid sequencing in one analytical setup (LC-MS/MS; Aebersold and Mann, 2003). Protein identification using LC-MS/MS is a concentration sensitive technique and an extraction technique that results in a higher intensity spot on 2D-PAGE will result in more peptides of higher abundance once trypsin digested. Thus, higher abundance peptides will produce more comprehensive fragmentation and thus sequence data (Aebersold and Mann, 2003), providing more confidence in the peptide identifications as observed in present study using the M-BPP method. In addition, as peptides of different compositions do not ionize with equal efficiencies, a higher concentration of protein and thus peptides obtained from trypsin digested protein spots in the present study increased the chances of detecting poorly ionizing peptides and lead to greater protein sequence coverage and more confidence in the protein identification. For $Z$. muelleri, all the twenty six excised protein spots were identified and classified into diverse functionally categories wherein the majority of them belong to biological, cellular and metabolic processes with catalytic, binding and transferase activities. For most of the identified proteins the PEAKS score ranged between 103.15 and 306.5 (except spot 13, score 64.81), with a high number of exclusive unique spectrum count (2-26), high number of exclusive peptide count (2-43), and high sequence coverage (15-81\%). There were few proteins wherein exclusive unique peptide count and/or exclusive unique spectrum count were low (spot 13, 16, 17, and 24), however their PEAKS score and sequence coverage were significantly higher confirming their identity. Many of these identified proteins have recently been found to be differentially regulated in photo-acclimation responses (Kumar et al., 2017). Specifically, malate dehydrogenase, glycine hydroxymethyl transferase, transketolase, inositol-3-phoaphate sysnthase, glutathione S-transferase, and phosphoglycerate kinase have been suggested to play crucial role in acclimation by providing extra energy requirements and enhancing antioxidants levels during high light induced stress (Kumar et al., 2017). Recently, the functionality of many of the identified proteins in this study has been discussed in other seagrasses species such as $P$. oceanica and $C$. nodosa for their involvement in acclimation/tolerance to low light, salinity and $\mathrm{CO}_{2}$ vents (Dattolo et al., 2013; Piro et al., 2015; Olivé et al., 2017; Procaccini et al., 2017). Similar to $Z$. muelleri, the identified proteins in P. australis were able to be categorized to diverse biological processes, localized to various cellular components, showing considerably high scores, higher exclusive unique peptide and spectrum counts, and sequence coverage.

Further, the proteins spots that were excised from the acidic region of $2 \mathrm{D}$ gel for $Z$. muelleri were successfully analyzed using LCMS/MS and identified as actin, huntingtininteracting protein $\mathrm{K}$, putative RNA binding protein, $60 \mathrm{~S}$ acidic ribosomal protein, however others were identified as hypothetical proteins, which is a common occurrence in all organisms and not restricted to plants. However, the proteins that were excised from the acidic region of $2 \mathrm{D}$ gel of $P$. australis were identified as profilin-1, ferrodoxin, rubisco activase, $60 \mathrm{~S}$ acidic ribosome protein, peroxiredoxin, RNA binding protein, ankyrin repeat containing protein, stromal heat shock protein, fructose bi-phosphatase, thiamine thiazole synthase, NADHubiquinone oxidoreductase, and ATPase-subunit. Many of these identified proteins specifically ferrodoxin, rubisco activase, actin, NADH-ubiquinone have recently been found to be differentially regulated in photo-acclimation responses (Kumar et al., 2017).

PEAKS analysis results revealed that the proteins spot selected for demonstration purpose in Z. muelleri (spot 6, Figure 3) was a $20 \mathrm{kDa}$ chaperonin and in $P$. australis (spot 2, Figure 4) was 5-methyltetrahydropteroyltriglutamate-homocysteine S-methyltransferase (commonly known as methionine synthasecobalamin independent) respectively. Recently, the crucial role of chaperonin and methionine synthase in providing tolerance to elevated light exposure in $Z$. muelleri has been evidenced (Kumar et al., 2017). A high quality peptide sequence match, annotated peptide mass spectrum and ion match summary obtained for both these and other randomly selected protein spots using LC/MS/MS suggested that the modified BPP 
method is compatible with MS and can be used for further proteome mapping of $Z$. muelleri and $P$. australis leaf tissues. BPP based protein extraction, 2D-IEF and subsequent analysis of differentially regulated proteins using MALDI-TOF-MS has been successfully employed in the halophytes S. europaea (Wang et al., 2007), T. halophile (Wang et al., 2013), and S. portulacastrum (Yi et al., 2014).

Finally, we successfully performed western blot analysis using the proteins extracted from M-BPP method for the detection of phosphoenolpyruvate carboxylase (PEPC-a key enzyme in carbon metabolism). Immunoreactive bands detected by the antiPEPC antibody were reported. As expected, a band at an apparent molecular mass of $110 \mathrm{kDa}$ was recognized. This band lies in the molecular mass range of $A$. thaliana PEPC (105-110 KDa). We could detect this protein efficiently while using a minimum of 5 $\mu \mathrm{g}$ of total protein. Recently, a significant down regulation of the PEPC transcript was observed in C. nodosa collected from $\mathrm{CO}_{2}$ vent site indicating an overall reduction of metabolic processes related with photosynthesis (Olivé et al., 2017).

\section{CONCLUSION}

By optimizing and modifying the BPP (M-BPP) method as described in this study, we succeed in obtaining a higher yield of proteins from seagrass ( $Z$. muelleri and P. australis) leaves. The obtained proteins from both the seagrasses are resolved into several hundreds to thousands of protein spots on 2D-PAGE. The improved method results in high quality 2D-PAGE spot patterns and immunoblots free from background smearing and streaking, without detrimentally affecting protein identification by LCMS/MS analysis. This method is rapid and requires only $1.5 \mathrm{~h}$ compared to the universal TASP method $(3 \mathrm{~h})$, and can be used for routine protein extraction from marine angiosperm plants for proteome mapping. To the best of our knowledge, this is the first time that the BPP method has been examined and modified for its successful implementation for the proteome analysis of marine macrophytes. Further, it is highly likely that the results of proteomic studies when integrated with allied omic platforms, such as transcriptomics or metabolomics, will provide better insights on the acclimation/tolerance mechanisms of seagrasses in response to natural and anthropogenic pressure. This will further deepen our understanding of systems biology and will allow identification of the metabolic pathways that are crucial for the survival of marine macrophytes under future climate change scenarios.

\section{REFERENCES}

Aebersold, R., and Goodlett, D. R. (2001). Mass spectrometry in proteomics. Chem. Rev. 101, 269-295. doi: 10.1021/cr990076h

Aebersold, R., and Mann, M. (2003). Mass spectrometry based proteomics. Nature 422, 198-207. doi: 10.1038/nature01511

Carpentier, S. C., Witters, E., Laukens, K., Deckers, P., Swennen, R., and Panis, B. (2005). Preparation of protein extracts from recalcitrant plant tissues: an evaluation of different methods for two-dimensional gel electrophoresis analysis. Proteomics 5, 2497-2507. doi: 10.1002/pmic.200401222

Gene Ontology Consortium (2015). Gene Ontology Consortium: going forward. Nucleic Acids Res. 43:D1049. doi: 10.1093/nar/gku1179

\section{AUTHOR CONTRIBUTIONS}

ZJ, MaK, MP, and PR conceived and designed research. ZJ, $\mathrm{MaK}$, and MPP performed 2D-IEF and protein identification using LC-MS/MS and analyzed the data. PD and MiK performed Western Blot analysis while kindly providing the primary and secondary antibodies, and standard for PEPC enzyme. MaK, ZJ, and MPP, wrote manuscript. TK assisted in bioinformatics analysis. $\mathrm{PR}$ revised and edit the manuscript. All authors read and approved the manuscript.

\section{ACKNOWLEDGMENTS}

Author MaK is grateful to the Australian Research Council for awarding him Discovery Early Career Research Award (DECRA Fellowship, DE150100461-2015). Author ZJ is grateful to the National Basic Research Program of China (2015CB452905) and the Natural Science Fund of Guangdong (nos. 2014A030 313734).

\section{SUPPLEMENTARY MATERIAL}

The Supplementary Material for this article can be found online at: http://journal.frontiersin.org/article/10.3389/fpls.2017. 01416/full\#supplementary-material

Supplementary Figure 1 | 2D-IEF analysis of extracted proteins from the leaf tissue of seagrass Zostera muelleri among the four protein extraction methodsphenol, P (A); TCA/acetone/SDA/Phenol, TASP (B); borax/polyvinyl pyrrolidone/phenol, BPP (C); and modified BPP, M-BPP (D) extraction, respectively, on linear gel strip pH 3-10. Randomly excised protein spots are encircled and marked with their corresponding numbers. The red boxes indicated the regions wherein few acidic protein spots were randomly excised and analyzed by nanoLC-MS-MS. The green circle represent the RuBisCO large subunit protein identified and reported by Kumar et al. (2017).

Supplementary Figure 2 | 2D-IEF analysis of extracted proteins from the leaf tissue of seagrass Posidonia australis among the four protein extraction methodsphenol, P (A); TCA/acetone/SDA/Phenol, TASP (B); borax/polyvinyl pyrrolidone/phenol, BPP (C); and modified BPP, M-BPP (D) extraction, respectively, on linear gel strip pH 3-10. Randomly excised protein spots are encircled and marked with their corresponding numbers. The red boxes indicated the regions wherein few acidic protein spots were randomly excised and analyzed by nanoLC-MS-MS.

Supplementary Table 1 | Identification of proteins using software PEAKS studio ver 8.0 from the excised spots resolved on 2DE (Listed in Tables 1, 2; and red encircled spots shown in Supplementary Figures 1, 2), analyzed by LC-MS/MS for seagrasses Zostera muelleri and Posidonia australis.

Costanza, R., De Groot, R., Sutton, P., Van Der Ploeg, S., Anderson, S. J., Kubiszewski, I., et al. (2014). Changes in the global value of ecosystem services. Glob. Environ. Change 26, 152-158. doi: 10.1016/j.gloenvcha.2014. 04.002

Dattolo, E., Gu, J., Bayer, P. E., Mazzuca, S., Serra, I. A., Spadafora, A., et al. (2013). Acclimation to different depths by the marine angiosperm Posidonia oceanica: transcriptomic and proteomic profiles. Front. Plant Sci. 4:195. doi: 10.3389/fpls.2013.00195

Davey, P. A., Pernice, M., Sablok, G., Larkum, A., Lee, H. T., Golicz, A., et al. (2016). The emergence of molecular profiling and omics techniques in seagrass biology; furthering our understanding of seagrasses. Funct. Integr. Genomics 16, 465-480. doi: 10.1007/s10142-016-0501-4 
Ferrat, L., Willie-Echevarria, S., Cates, R. G., Pergent-Martini, C., Pergent, G., Zou, J., et al., (2012). "Posidonia oceanica and Zostera marina as potential biomarkers of heavy metal contamination in coastal systems," in Ecological Water Quality - Water Treatment and Reuse, eds K. Voudouris and D. Voutsa (Intech Open access), 325-342.

Finn, R. D., Attwood, T. K., Babbitt, P. C., Bateman, A., Bork, P., Bridge, A. J., et al. (2017). InterPro in 2017-beyond protein family and domain annotations. Nucleic Acids Res. 45, D190-D199. doi: 10.1093/nar/gkw1107

Garcia, J. L., Avidan, N., Troncoso, A., Sarmiento, R., and Lavee, S. (2000). Possible juvenile-related proteins in olive tree tissues. Sci. Hortic. 85, 271-284. doi: 10.1016/S0304-4238(00)00123-0

Hu, J., Rampitsch, C., and Bykova, N. V. (2015). Advances in plant proteomics toward improvement of crop productivity and stress resistancex. Front. Plant Sci. 6:209. doi: 10.3389/fpls.2015.00209

Isaacson, T., Damasceno, C. M., Saravanan, R. S., He, Y., Catalá, C., Saladié, M., et al. (2006). Sample extraction techniques for enhanced proteomic analysis of plant tissues. Nat. Protoc. 1, 769-774. doi: 10.1038/nprot.2006.102

Kumar, M., Kumari, P., Trivedi, N., Shukla, M. K., Gupta, V., Reddy, C. R. K., et al. (2011). Minerals, PUFAs and antioxidant properties of some tropical seaweeds from Saurashtra coast of India. J. Appl. Phycol. 23, 797-810. doi: 10.1007/s10811-010-9578-7

Kumar, M., Kuzhiumparambil, U., Pernice, M., Jiang, Z., and Ralph, P. J. (2016). Metabolomics: an emerging frontier of systems biology in marine macrophytes. Algal Res. 16, 76-92. doi: 10.1016/j.algal.2016.02.033

Kumar, M., Padula, M. P., Davey, P., Pernice, M., Jiang, Z., Sablok, G., et al. (2017). Proteome analysis reveals extensive light stress-response reprogramming in the seagrass Zostera muelleri (Alismatales, Zosteraceae) metabolism. Front. Plant Sci. 7:2023. doi: 10.3389/fpls.2016.02023

Kuzhiumparambil, U., Kumar, M., and Ralph, P. (in press). "Gas and liquid chromatography-mass spectrometry-based metabolic profiling of marine angiosperm Zostera muelleri (Alismatales, Zosteraceae)," in Systems Biology of Marine Ecosystems: Molecular Ecology, eds M. Kumar and P. Ralph (Springer International Publishing).

Larkum, A., Orth, R. J., and Duarte, C. (2006). Seagrass: Biology, Ecology and Conservation. Dordrecht: Springer.

Luche, S., Santoni, V., and Rabilloud, T. (2003). Evaluation of nonionic and zwitterionic detergents as membrane protein solubilizers in two-dimensional electrophoresis. Proteomics 3, 249-253. doi: 10.1002/pmic.200390037

Macreadie, P., Schliep, M., Rasheed, M., Chartrand, K., and Ralph, P. (2014). Molecular indicators of chronic seagrass stress: a new era in the management of seagrass ecosystems? Ecol. Indic. 38, 279-281. doi: 10.1016/j.ecolind.2013.11.017

Mazzuca, S., Spadafora, A., Filadoro, D., Vannini, C., Marsoni, M., Cozza, R., et al. (2009). Seagrass light acclimation: 2-DE protein analysis in Posidonia leaves grown in chronic low light conditions. J. Exp. Mar. Biol. Ecol. 374, 113-122. doi: 10.1016/j.jembe.2009.04.010

McCarthy, F. M., Wang, N., Magee, G. B., Nanduri, B., Lawrence, M. L., Camon, E. B., et al. (2006). AgBase: a functional genomics resource for agriculture. BMC Genomics 7:229. doi: 10.1186/1471-2164-7-229

Migliore, L., Rotini, A., Randazzo, D., Albanese, N. N., and Giallongo, A. (2007). Phenols content and 2-D electrophoresis protein pattern: a promising tool to monitor Posidonia meadows health state. BMC Ecol. 7:6. doi: 10.1186/1472-6785-7-6

Olivé, I., Silva, J., Lauritano, C., Costa, M. M., Ruocco, M., Procaccini, G., et al. (2017). Linking gene expression to productivity to unravel long-and short-term responses of seagrasses exposed to $\mathrm{CO}_{2}$ in volcanic vents. Sci. Rep. 7:42278. doi: $10.1038 /$ srep 42278

Olsen, J. L., Rouzé, P., Verhelst, B., Lin, Y.-C., Bayer, T., Collen, J., et al. (2016). The genome of the seagrass Zostera marina reveals angiosperm adaptation to the sea. Nature 530, 331-335. doi: 10.1038/nature16548

Papenbrock, J. (2012). Highlights in Seagrasses' Phylogeny, Physiology, and Metabolism: what makes them special? ISRN Bot. 2012:103892. doi: $10.5402 / 2012 / 103892$

Piro, A., Marín-Guirao, L., Serra, I. A., Spadafora, A., Sandoval-Gil, J. M., Bernardeau-Esteller, J., et al. (2015). The modulation of leaf metabolism plays a role in salt tolerance of Cymodocea nodosa exposed to hypersaline stress in mesocosms. Front. Plant Sci. 6:464. doi: 10.3389/fpls.2015.00464

Procaccini, G., Ruocco, M., Marínguirao, L., Dattolo, E., Brunet, C., D'esposito, D., et al. (2017). Depth-specific fluctuations of gene expression and protein abundance modulate the photophysiology in the seagrass Posidonia oceanica. Sci. Rep. 7:42890. doi: 10.1038/srep42890

Serra, I. A., and Mazzuca, S. (2011). "Posidonia oceanica: from ecological status to genetic and proteomic resources," in Seagrass: Ecology, Uses and Threats, ed R. S. Pirog (New York, NY: Nova Science Publishers), 71-116.

Singh, N., Jain, N., Kumar, R., Jain, A., Singh, N. K., and Rai, V. (2015). A comparative method for protein extraction and 2-D gel electrophoresis from different tissues of Cajanus cajan. Front. Plant Sci. 6:606. doi: 10.3389/fpls.2015.00606

Spadafora, A., Filadoro, D., Mazzuca, S., Bracale, M., Marsoni, M., Cardilio, M., et al. (2008). 2-DE polypeptide mapping of Posidonia oceanica leaves, a molecular tool for marine environment studies. Plant Biosys. 142, 213-218. doi: 10.1080/11263500802150316

Tian, W. M., Wu, J. L., Hao, B. Z., and Hu, Z. H. (2003). Vegetative storage proteins in the tropical tree Swietenia macrophylla: seasonal fluctuation in relation to a fundamental role in the regulation of tree growth. Can. J. Bot. 81, 492-500. doi: 10.1139/b03-045

Vâlcu, C., and Schlink, K. (2006). Efficient extraction of proteins from woody plant samples for two-dimensional electrophoresis. Proteomics 6, 4166-4175. doi: 10.1002/pmic.200500660

Wang, D., Sun, Y., Tong, Z., Yang, Q., Chang, L., Meng, X., et al. (2016). A protein extraction method for low protein concentration solutions compatible with the proteomic analysis of rubber particles. Electrophoresis 37, 2930-2939. doi: 10.1002/elps.201600172

Wang, X., Chang, L., Tong, Z., Wang, D., Yin, Q., Wang, D., et al. (2016). Proteomics profiling reveals carbohydrate metabolic enzymes and 14-3-3 proteins play important roles for starch accumulation during Cassava root tuberization. Sci. Rep. 6:19643. doi: 10.1038/srep19643

Wang, X., Chang, L., Wang, B., Wang, D., Li, P., Wang, L., et al. (2013). Comparative proteomics of Thellungiella halophila leaves from plants subjected to salinity reveals the importance of chloroplastic starch and soluble sugars in halophyte salt tolerance. Mol. Cell. Proteomics 12, 2174-2195. doi: 10.1074/mcp.M112.022475

Wang, X., Li, X., Deng, X., Han, H., Shi, W., and Li, Y. (2007). A protein extraction method compatible with proteomic analysis for the euhalophyte Salicornia europaea. Electrophoresis 28, 3976-3987. doi: 10.1002/elps.2006 00805

Wang, X., Shi, M., Lu, X., Ma, R., Wu, C., Guo, A., et al. (2010). A method for protein extraction from different subcellular fractions of laticifer latex in Hevea brasiliensis compatible with 2-DE and MS. Proteome Sci. 8, 1-10. doi: 10.1186/1477-5956-8-35

Waycott, M., Duarte, C. M., Carruthers, T. J., Orth, R. J., Dennison, W. C., Olyarnik, S., et al. (2009). Accelerating loss of seagrasses across the globe threatens coastal ecosystems. Proc. Natl. Acad. Sci. U.S.A. 106, 12377-12381. doi: 10.1073/pnas.0905620106

Wu, X., Gong, F., and Wang, W. (2014a). Protein extraction from plant tissues for 2DE and its application in proteomic analysis. Proteomics 14, 645-658. doi: 10.1002/pmic.201300239

Wu, X., Xiong, E., Wang, W., Scali, M., and Cresti, M. (2014b). Universal sample preparation method integrating trichloroacetic acid/acetone precipitation with phenol extraction for crop proteomic analysis. Nat. Protoc. 9, 362-374. doi: 10.1038/nprot.2014.022

Yi, X., Sun, Y., Yang, Q., Guo, A., Chang, L., Wang, D., et al. (2014). Quantitative proteomics of Sesuvium portulacastrum leaves revealed that ion transportation by V-ATPase and sugar accumulation in chloroplast played crucial roles in halophyte salt tolerance. J. Proteomics 99, 84-100. doi: 10.1016/j.jprot.2014.01.017

Conflict of Interest Statement: The authors declare that the research was conducted in the absence of any commercial or financial relationships that could be construed as a potential conflict of interest.

Copyright (c) 2017 Jiang, Kumar, Padula, Pernice, Kahlke, Kim and Ralph. This is an open-access article distributed under the terms of the Creative Commons Attribution License (CC BY). The use, distribution or reproduction in other forums is permitted, provided the original author(s) or licensor are credited and that the original publication in this journal is cited, in accordance with accepted academic practice. No use, distribution or reproduction is permitted which does not comply with these terms. 